\title{
PATTERNS OF PEDOTURBATION BY TREE UPROOTING IN FOREST SOILS
}

\section{V. Bobrovsky}

Institute of Physico-Chemical and Biological Problems in Soil Science of RAS, 2 Institutskaya street, Pushchino, 142290, Russia E-mail: maxim.bobrovsky@gmail.com

\section{S. V. Loyko}

Tomsk State University, 36 Lenina street, Tomsk, 634050, Russia

E-mail: s.loyko@yandex.ru

\section{СЛЕДЫ ВЫВАЛОВ В ЛЕСНЫХ ПОЧВАХ}

\section{М. В. Бобровский}

Институт физико-химических и биологических проблем почвоведения РАН, 142290, Россия, г. Пущино, ул. Институтская, 2 E-mail: maxim.bobrovsky@gmail.com

\section{С. В. Лойко}

Томский государственный университет, 634050, Россия, г. Томск, ул. Ленина, 36 E-mail: s.loyko@yandex.ru

Abstract. The fall of a tree accompanied by its uprooting is the most common natural end of the tree life. To understand how soil is affected by treefalls, it is necessary to recognize their signs in soil profiles, even when their surface features (pit-and-mound topography) are erased. The paper reviews these signs of treefalls in soil profiles, which can be used to distinguish the patterns of old treefall-related pedoturbations. The paper is based on a literature analysis and results of authors' long-term studies of forest soil in the European part of Russia and in the Western Siberia. Two main types of uprooting of a falling tree (hinge and rotational treefalls) are considered. The paper presents data on the sizes of 424 pit-and-mound soil complexes for nine tree species (Tilia cordata, Acer platanoides, Fraxinus excelsior, Ulmus glabra, Quercus robur, Betula pendula, Populus tremula, Picea abies and Pinus sylvestris) and describes peculiarities of soil relocation in the process of different treefalls, which is necessary to recognize old treefall complexes in soil profiles. The following soil-profile signs of treefalls are considered: (1) treefall pits (cauldrons); (2) spotty or streaky structures of different degrees of contrast; (3) blocks of "buried material" from the upper soil layers; (4) washed (bleached) material depositing at the bottom of pits and filling soil pores and channels of various origins; (5) signs of hydrogenous changes of soil material resulting from water stagnation in the pits; (6) root channels at the bottom of the pit and (7) inclusions of litter and charcoal. As shown by our studies, treefall-related pedoturbations affect soil profiles at a depth larger than the depth usually described by the soil horizons A, E, Bhs, etc. A conclusion is made that in most forest soils, the middle and lower parts of profiles have patterns originating from the transfer of soil material upon treefalls.

Key words: soil formation, tree uprooting, pit-and-mound topography, soil disturbance, soil morphology.

For citation: Bobrovsky M.V., Loyko S.V. Patterns of pedoturbation by tree uprooting in forest soils. Russian Journal of Ecosystem Ecology. 2016;1(1). Available from: https://doi.org/10.21685/2500-0578-2016-1-3

Аннотация. Ветровал с выворачиванием почвенного кома является одним из наиболее распространенных результатов естественного отмирания деревьев. Для осознания масштабов влияния ветровалов на почву нужно хорошо видеть их признаки в почвенном профиле независимо от наличия их следов (ветровального микрорельефа) на поверхности. Цель настоящей статьи - обзор признаков, по которым можно распознать старые ветровальные нарушения в профилях лесных почв. Статья базируется на анализе литературы и результатах авторских исследований лесных почв на территориях Европейской России и Западной Сибири. Рассмотрены особенности формирования двух основных типов вывалов: образованного в результате поворота почвенного кома (непровернутый) и вращения с движением кома назад в западину (провернутый). Приведены параметры разных элементов вывалов по результатам измерений 424 пар бугорзападина для девяти видов деревьев: Tilia cordata, Acer platanoides, Fraxinus excelsior, Ulmus glabra, Quercus 
robur, Betula pendula, Populus tremula, Picea abies, Pinus sylvestris. Описаны особенности перемещения материала почвы вывалами разных типов, важные для различения признаков старых ветровалов в профилях. Рассмотрены признаки вывалов в почвенном профиле, различимые после разрушения ветровального микрорельефа на поверхности: (1) собственно ветровальные западины (котлы); (2) пятнистые и полосчатые структуры из материала разной степени контрастности, в том числе отдельные изолированные комки/пятна; (3) блоки «погребенного» материала верхних горизонтов (гумусового, элювиального); (4) перемытый отбеленный при эрозии материал, оседающий на дне западины, а также заполняющий поры и каналы различного происхождения; (5) признаки гидрогенных изменений материала почвы, формирующиеся в результате застаивания влаги в западине; (6) корневые ходы, ассоциированные с нижней границей западины; (7) включения в виде подстилки или углей. Исследования показали, что вывальные педотурбации затрагивали профиль на глубине большей, чем глубина современных типодиагностических горизонтов (А, Е, ВFН и др.). Строение средних и нижних частей профилей большинства лесных почв в разной мере обязано своим происхождением перемещению материала почвы при образовании вывалов.

Ключевые слова: генезис почв, веровал, ветровальный почвенный комплекс, нарушения почв, почвенная морфология.

\section{Introduction}

One of the most common ways of natural dying of trees in a forest is their fall with uprooting. There is a lot of literature considering the mechanisms of formation of windfall wood, the treefallrelated changes in the soil and vegetation cover and the role of treefall in the dynamics of ecosystems [1-21].

A question of special interest is the role of treefall in formation and alteration of soil. There are several reviews of the problem [9, 12, 22-27], including recent ones [28-32], which free us from a necessity to give a detailed account of the state of the art in the field.

Most of the works studying the effect of treefall on soils rest upon the following theses.

1. The impact that a falling tree has on soil is viewed as a disturbance. This is the same kind of problem that ecologists tried to solve within the framework of disturbance theory $[11,16,33]$. In ecology, formation of gaps because of treefall used to be considered a disturbance too: and disturbance it is as far as monotonous secondary even-aged forests are concerned. The ideas of gap paradigm and mosaic-cyclic concept changed this view [34-38]. Nowadays, gaps and fallen trees are considered as the main elements of mosaics of forest communities: the fall of uneven-aged trees determines the continuity of microsuccessions and the steady state of forest ecosystems.

2. The treefall-related pedoturbations are viewed as exclusive events. Exceptions from this rule are works on the "perturbation model" of soil development $[26,39,40]$. However, this model is perceived not as natural and dominating in forest ecosystems but rather supplementary. In addition, most of those models assume that treefall disturbs pedogenesis, reducing soils.

Most of the works examine treefalls whose signs are clearly seen on the soil surface (pit-and- mound topography). Very few papers analyze signs preserved in the soil after natural or anthropogenic erasure of the pit-and-mound signs on the soil surface [18, 25, 41-43].

The idea that treefall signs can be discerned in the soil profile independently of the extent of preservation of pit-and-mound topography was most logically and fully described by Ponomarenko $[18,44]$. Her ideas and methods are being developed by us in this article.

To evaluate the extent of influence of treefall on a soil, one should be able to discern the signs of treefall in soil profiles even when the soil does not show any signs of pit-and-mound topography. The objective of the paper is to review such signs in soil profiles and show how they can be used to distinguish patterns of pedoturbation in forests caused by tree uprooting. The paper is based on results of long-term studies of forest soil in the European part of Russia and in the Western Siberia [21, 42, 43, 45-47].

\section{Types of treefalls}

First of all, let us consider the types of uprooting of a falling tree, since the corresponding pattern of pedoturbation will depend on how the tree falls.

By now, different variants of treefalls have been described, and several classifications of the corresponding soil patterns have been suggested $[5,9,12,14,18,24,25,48-50]$.

The main qualifying trait in the classifications suggested is the character of movement of a tree trunk in the process of its fall and the position of a root ball material in relation to the pit right after uprooting.

As a result, a large number of treefall types can be distinguished. In this paper, we shall enlarge upon 
two basic types of treefalls found on plains: hinge and rotational treefalls (according to [12]).

1. Hinge treefalls are formed when a tree pivots on the edge of a root mat, uplifting the root mat and attached soil (Fig. 1,A). Some roots do not snap and keep their contact with soil, the root ball hangs above the pit, and the mound is formed on the front (leeward) side of the pit (Fig. 2,A-C). This variant of treefall corresponds to the following types of uprooting: typical [5], simple [14], windthrow with plate-like rootballs [24], "notcranked" or "not-turned" uprooting [18], and "complete treefall, when the roots opposite to the wind direction snap off close to the trunk" [25].

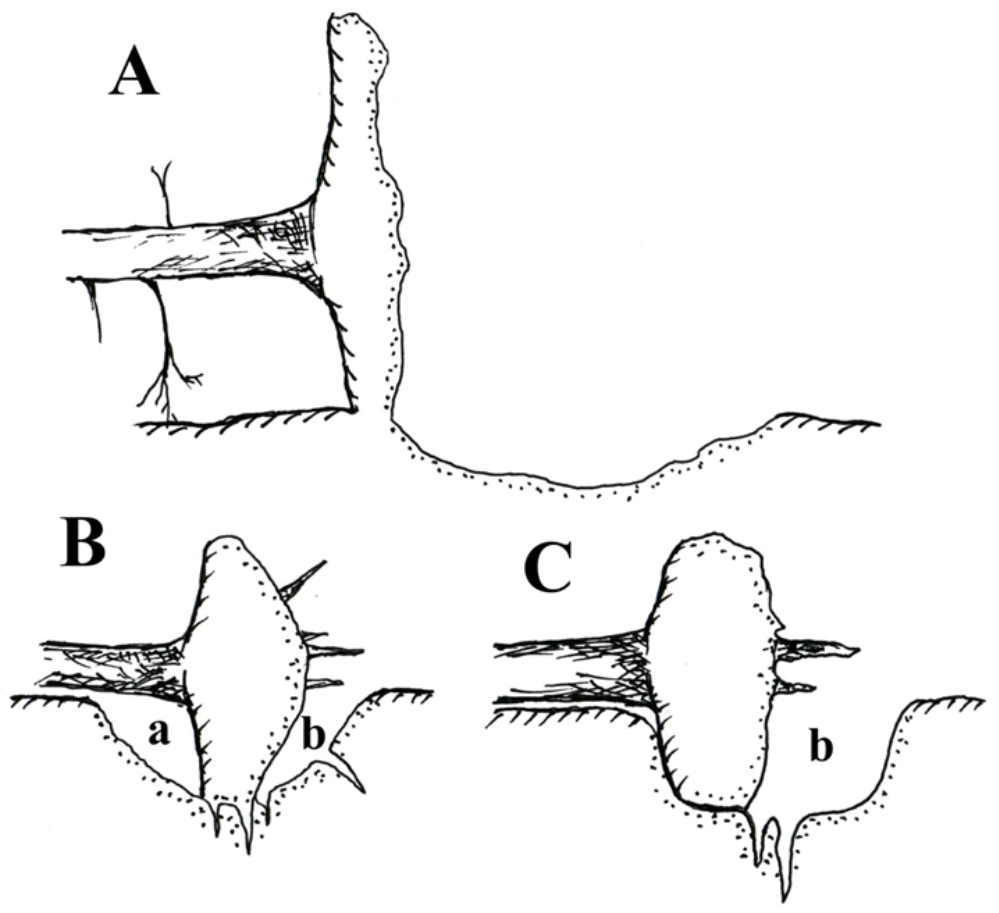

Fig. 1. Hinge $(A)$ and rotational $(B, C)$ treefalls with uprooting: $a$ the front and $b$ the back parts of the pits

2. Rotational treefalls result from a ball and socket type rotation of ball root mass, with shearing of roots around the edges (Fig. 1,B,C). All roots of the tree snap off, and the root ball is displaced backward and slips back into the pit (Fig. 2, $D-H)$. This variant of treefall corresponds to the following types of uprooting: "untypical" or "with trunk movement back" [5], one of the variants of complex uprooting [14], ball-and-socket windthrow [24], "cranked" or 'turned' uprooting [18], and "complete treefall, with the tree stump tilted vertically but completely situated within the original micro-depression" [25].

Upon rotational treefalls, the tree trunk will be situated lower than it will be upon hinge treefalls (with comparable sizes of the root ball) (Fig. 1, 2). Hinge treefalls are most typical for trees with a shallow root system. They are often vegetatively renewed trees (e.g., coppice limes) or trees grown on soils with low thickness of the layer where roots can be located because of over moisture, permafrost, rocky bed, etc.

A type of treefall will depend on how much of soil material is carried along with the roots upon the fall and it will depend on the shape of the root ball and the pit as well. The heavier and more bulgy is the ball of transferred soil material, the higher is the probability of formation of rotational treefall.

In the case of rotational treefalls, the distance at which the trunk and the material of the mound are displaced also depends on the shape of the pit. With a bowl-shaped (spherical) pit and, respectively, a bulged mound, the probability of the mound material to be shifted closer to the center of the pit is higher. In this case, the pit is divided by the mound into two parts: (1) the front part of the pit, between the edge of the pit and the front (leeward) side of the mound and (2) the back part of the pit, between the edge of the pit and the back (windward) side of the mound (Fig. 1,B).

If the shape of the pit resembles a parallelepiped, the backward displacement of the root ball material is usually restricted to «slipping» into the flat pit: the front side of the mound joins the edge of the pit, with only the back part of the pit visible (Fig. 1,C). When viewed from the windward side, the pit is substantially smaller than the mound; it happens in contrast to hinge treefalls, when the areas of the mound and pit projections are similar. 


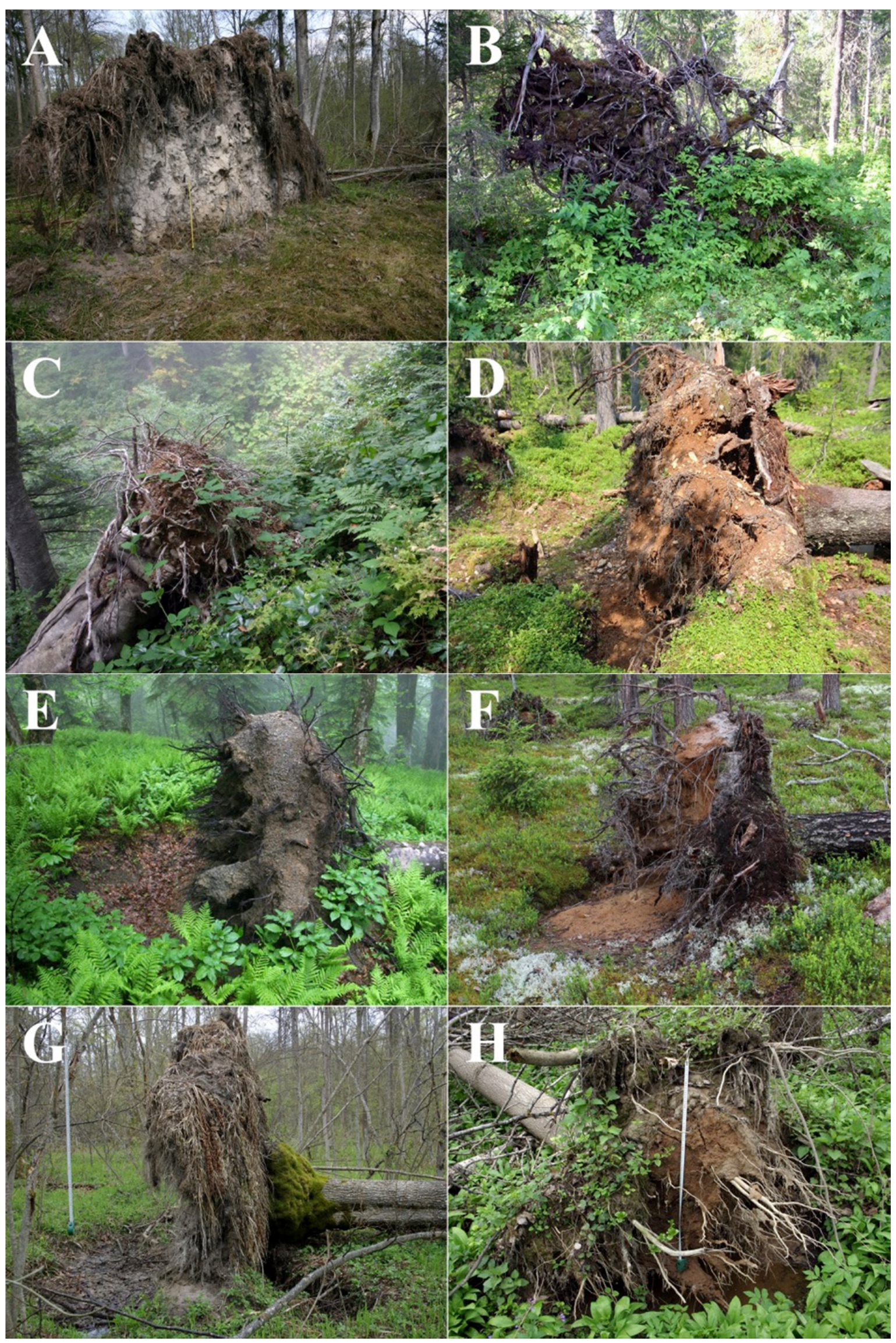

Fig. 2. Hinge $(A-C)$ and rotational (D-E) treefalls with uprooting: $A$ - Picea abies (Kaluga region); $B$ - Picea obovata

(Ural Mountains, the Komi Republic); C - Fagus orientalis (Caucasus Mountains, Krasnodar region);

D - Picea obovata (Ural Mountains, the Komi Republic); E - Abies nordmanniana (Caucasus mountains, Krasnodar region); F - Pinus sylvestris (Ural mountains, the Komi Republic); G - Acer platanoides (Kaluga region); $\mathrm{H}$ - Fraxinus excelsior (Kaluga region) 


\section{Sizes of pedoturbation patterns related to the fall of various tree species}

Studying treefall-related patterns of pedoturbation in the soil profiles, one should take into account the linear sizes of pit-and-mound microtopography; first of all, the sizes of the pits.

The sizes of windthrow microtopography depend on many factors: the type and size of a tree, the extent of development of its root system, the type of treefall, etc. $[12,18,25]$. In this paper, we shall not give a detailed analysis of all these factors, limiting ourselves to a few examples illustrating the common sizes of pit/mound pairs.

The Table 1 shows parameters of 424 contemporary pit/mound pairs formed upon the fall with uprooting of trees of nine species [21]; the measurements were conducted in 2007 and 2009 in temperate forests in the State Nature Reserve «Kaluzhskie Zaseki» (Kaluga region, Russia). The results of the analysis of treefall-related pedoturbations showed that for all the tree species examined on that territory, the number of rotational treefalls was much higher than that of hinge treefalls. For elms (Ulmus glabra), only single hinge treefalls occurred. For common birches (Betula pendula), Norway maples (Acer platanoides) and aspens (Populus tremula), the part of hinge treefalls was less than $10 \%$ of their total number. For Norwegian spruces (Picea abies), limes (Tilia cordata) and ashes (Fraxinus excelsior), it was about $20 \%$; for oaks (Quercus robur), about $40 \%$. All the pine (Pinus sylvestris) treefalls found were rotational. The analysis showed that for most tree species, the average parameters of pit-and-mound microtopography were close (Table 1).

Table 1

Means and standard deviations of pit-and-mound microtopography sizes for various tree species (the State Nature Reserve «Kaluzhskie Zaseki»)

\begin{tabular}{|c|c|c|c|c|c|c|c|}
\hline \multirow[b]{2}{*}{ Tree species } & \multicolumn{2}{|c|}{ Mound } & \multicolumn{3}{|c|}{ Pit } & \multirow[b]{2}{*}{$\mathrm{Dbh}^{\dagger}, \mathrm{cm}$} & \multirow[b]{2}{*}{$\mathrm{n}^{\dagger \dagger}$} \\
\hline & Height, $\mathrm{cm}$ & Width, cm & Depth, cm & $\begin{array}{c}\text { Front part } \\
\text { of the pit }{ }^{*}, \mathrm{~cm}\end{array}$ & $\begin{array}{c}\text { Back part } \\
\text { of the pit, } \mathrm{cm}\end{array}$ & & \\
\hline Tilia cordata & $245 \pm 13$ & $119 \pm 8$ & $67 \pm 3$ & $30 \pm 9$ & $112 \pm 8$ & $28 \pm 1$ & 54 \\
\hline Acer platanoides & $259 \pm 13$ & $138 \pm 6$ & $67 \pm 3$ & $40 \pm 9$ & $140 \pm 12$ & $34 \pm 1$ & 46 \\
\hline Fraxinus excelsior & $291 \pm 15$ & $163 \pm 8$ & $68 \pm 2$ & $49 \pm 3$ & $170 \pm 12$ & $37 \pm 2$ & 52 \\
\hline Ulmus glabra & $237 \pm 16$ & $122 \pm 7$ & $62 \pm 3$ & $42 \pm 12$ & $117 \pm 9$ & $32 \pm 2$ & 39 \\
\hline Quercus robur & $375 \pm 19$ & $192 \pm 13$ & $90 \pm 5$ & $40 \pm 6$ & $188 \pm 18$ & $60 \pm 4$ & 20 \\
\hline Betula pendula & $261 \pm 9$ & $146 \pm 5$ & $63 \pm 2$ & $24 \pm 6$ & $158 \pm 8$ & $34 \pm 1$ & 73 \\
\hline Populus tremula & $236 \pm 10$ & $129 \pm 5$ & $80 \pm 4$ & $19 \pm 6$ & $130 \pm 7$ & $39 \pm 1$ & 89 \\
\hline Picea abies & $338 \pm 19$ & $192 \pm 11$ & $62 \pm 3$ & $39 \pm 6$ & $181 \pm 13$ & $44 \pm 2$ & 57 \\
\hline Pinus sylvestris & $290 \pm 17$ & $104 \pm 8$ & $149 \pm 13$ & $41 \pm 4$ & $100 \pm 0$ & $39 \pm 2$ & 8 \\
\hline
\end{tabular}

${ }^{*}$ For rotational treefalls only; ${ }^{\dagger}$ diameter of tree trunk at the height of $1,3 \mathrm{~m} ;{ }^{\dagger \dagger}$ number of pit-mound pairs measured.

The highest values of average mound height and pit area were registered for spruces. Among broad-leaved trees, the largest treefall-related soil complexes were formed by ashes. The highest average pit depth was found for Scots pine treefalls. Among deciduous tree species, the deepest pits were registered for oaks; second to them were aspen pits.

Similar data on pit depths we obtained in the studies of treefalls in other regions. For example, in the State Nature Reserve «Basegi» (Sverdlovsk region, Russia), the average depth of pits was $77 \pm 4 \mathrm{~cm}(n=28)$ for Picea obovata, $59 \pm 4 \mathrm{~cm}$ $(n=27)$ for Abies sibirica, and $63 \pm 6 \mathrm{~cm}(n=16)$ for Betula spp. (catastrophic windthrow in 2003, measurements of 2004). In the National Park «Russkiy Sever» (Vologda region, Russia), the depth of Picea abies pits varied from 30 to $85 \mathrm{~cm}$; the depth of Populus tremula pits from 50 to $150 \mathrm{~cm}$ and of Pinus sylvestris from 100 to $170 \mathrm{~cm}$.
Treefall-related soil microtopography is often studied on the data of spruce (Picea abies and $P$. obovata) treefalls (see $[9,26,40])$. Typical for the spruces considered are hinge treefalls (Fig. 2,A,B), although spruces often form rotational treefalls (Fig. 2,D). For example, rotational falls prevail among spruce treefalls in the Reserve «Kaluzhskie Zaseki»; their pits can be as deep as $150 \mathrm{~cm}$ and have a forward wedge up to $70 \mathrm{~cm}$ wide.

In nemoral-boreal and boreal forests, we also often found slightly rotational spruce treefalls, when the trunk moved backward at a distance of tens of centimeters. As a result, the material of the upper mineral horizon(s) was transferred into the pit and the litter material fell partially into the pit and partially on the soil surface from the side of the fallen trunk. In contrast to the prevailing opinion that the pits of spruce treefalls are shallow, our data show 
that the central part of spruce pits is usually several tens of centimeters deep. The impression of shallowness probably arises due to a large area of spruce pits, which predominantly have a saucer shape.

\section{Pit and mound development}

In order to recognize the signs of old treefalls in a soil profile, one should know how the treefallrelated patterns of pedoturbation are formed, i.e., how the soil material is relocated with time after treefalls of different types.

Peculiarities of crumbling of the mound material after treefalls are described in detail for all the abovementioned treefall types by Skvortsova et al. [9], Beatty and Stone [12], Ponomarenko [18], Langohr [25] and for rotational treefalls by Dzięgielewski [41].

The picture on the wall of a soil profile (pattern) differs for rotational and hinge treefalls. To a large extent, the position of the mound in relation to the pit determines transfer of the soil material after a treefall and it determines the final soil pattern as well.
In the case of hinge treefalls, the pit usually has a saucer shape. The front plane of the treefallrelated soil complex is outside the pit, and the root ball hangs above the pit (Fig. 2,A,B). As a result, the whole root ball material is relocated; sometimes with the exception of the material at the base of the mound, which turns around and remains at the same place.

The litter and particles of the mineral soil from the front plane of the ball fall on the soil surface unperturbed by the treefall (i.e. on the ground vegetation and the litter), forming a «buried soil» (Fig. 3). The litter or the humus horizon of the unperturbed soil covered by the turned-up material of the litter and the upper layer of the ball mineral soil form a characteristic pattern of the frontal (windward) part of the soil complex, resulted from a hinge treefall. If the mound is destroyed by some external impact, the pattern will be destroyed as well. Accordingly, we will not be able to see this part of hinge treefall patterns in the soil after, for example, ploughing up.
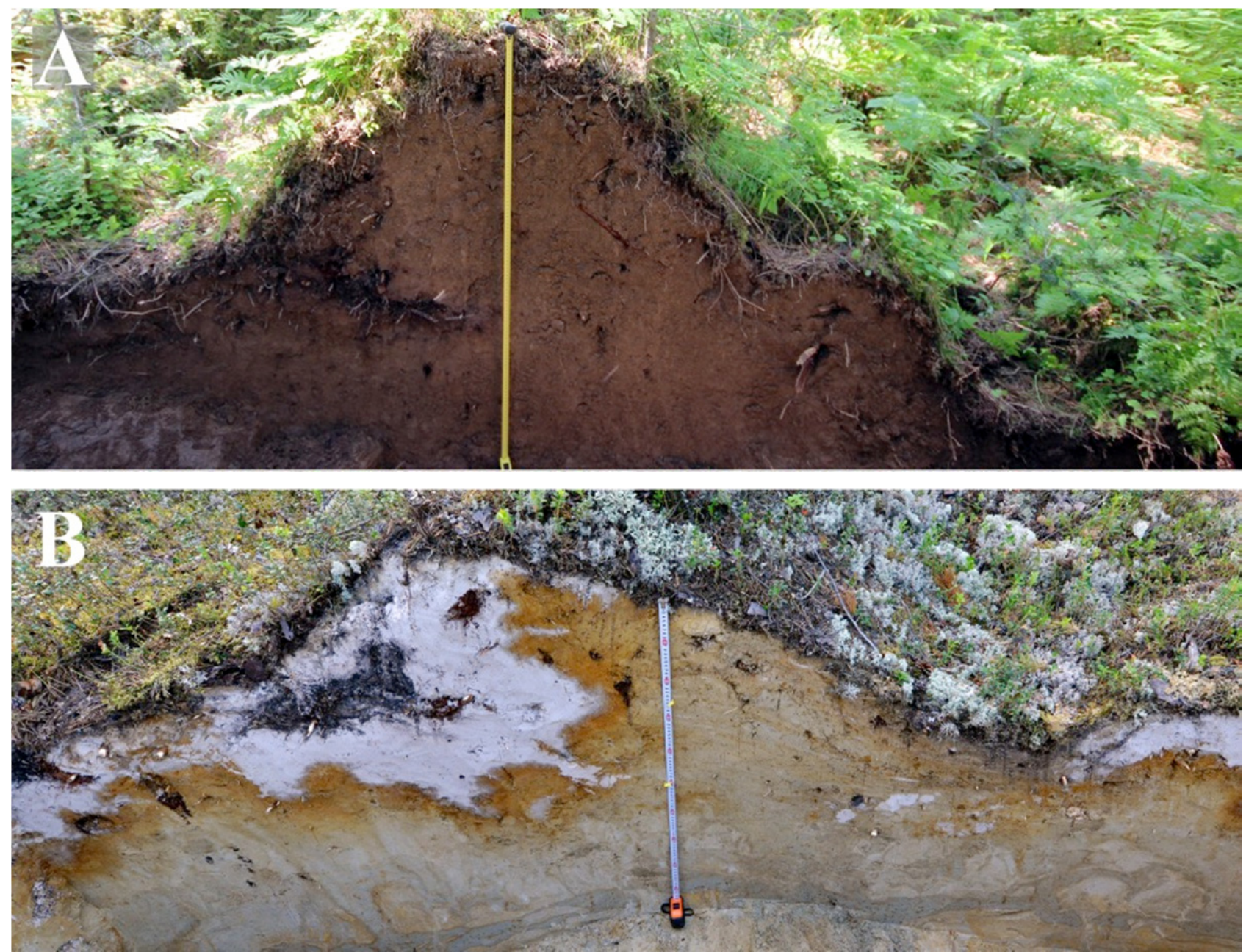

Fig. 3. Old pit-and-mound complexes caused by hinge treefalls:

A - Picea obovata, Haplic Cambisol (Ural Mountains, the Komi Republic);

B - Pinus sylvestris, Haplic / Entic Podzol (Krasnoyarsk region) 
The open surfaces of both the ball and the pit are subjected to erosion. Soil erosion involves 'work' through a three-stage process: detachment, transport and deposition of soil matter [51]. Soil erosion begins with detachment, which is caused by breakdown of aggregates (i.e., organo-mineral complexes leading to formation of domain, microaggregates and aggregates), by raindrop impact, shearing or drag force of water and wind. In soils of high structural stability, erosion is limited. It is also hindered when the mound and the pit are covered by plants which grew at the moment of treefall or new ones.

In the case of hinge treefalls, the root ball does not lid the pit and the area of eroded material, both on the ball and in the pit, can be large. The crumbled material (sediments) can be only found at the basis of the tree, where it forms a mound. The longer is the distance from the tree base, the larger is the part of transported material. In the backward (leeward) part of the pit, there are only sediments. If the pit is deep enough, this pattern can be seen even after such strong impacts as ploughing up.

Sediments represent a slightly changed soil material, which usually has a lumpy structure. As a rule, the material washed and transferred by water is sorted by granulometric fractions and has a microlamellar texture. The layers (lamellae) differ by their granulometric composition and consist of the material of different density.

Under extremely dry or damp conditions, plants slowly cover the pit. Under damp conditions, especially on dense clay loams, temporary or longstanding pools (puddles) can be formed in the pits and the soil material within and under the pit changes in the process of gleization.

In the case of rotational treefalls, the pit usually has a shape of a hemisphere or a parallelepiped. The entire root ball is located within the boundaries of the pit.

If the ball shifts towards the center or to the backward part of the pit, all the material of the litter and the upper soil layer from the frontal part of the ball will fall into the front part of the pit. This is a «calling card» of rotational treefall complexes $[18,21,25]$. This pattern is preserved in the profile even after strong impacts on the upper layer of the soil (Fig. 4).

If the ball shifts back approximately the length of the complex (the thickness of the root ball) and the frontal surface of the ball adjoins the front wall of the pit, the litter and the material of the upper soil layer are partially transferred to the front part of the pit, because of rotation. This pattern can be preserved in the profile even if the upper soil layer is substantially perturbed. Another part of the material of the litter and upper soil layer falls forward and covers the surface of the "unperturbed soil" like in the case of hinge treefall complexes. And similarly to hinge treefalls, this pattern is also destroyed by any impacts.

The backward part of rotational treefall complexes is often bulgy; the ball lids the most part of the pit. As a result, the ball and pit soil is usually not as eroded as at hinge treefalls. The soil material from the unperturbed areas adjacent to the pit is often transferred (falls or transported with water) into the back part of the pit. Accordingly, this material marks the backward part of the pit. The resulting pattern is also characteristic of rotational treefalls.

The lower, central part of the ball, which was on the leeward side before the treefall, does not crumble, being fixed between the material fallen from the frontal and backward surfaces of the ball. Its color and structure correspond to the initial soil (taking into account the rotation).

In the case of both hinge and rotational treefalls, blocks of the root ball material drop down, and the rate thereof may be different. The rate of sedimentation depends on the shape of the mound, properties of the soil material (first of all, its cohesion) and the rate and character of the mound and pit covering with vegetation (shielding and cementing of the soil material by plants).

Usually, the material from the frontal part of the ball and the bulged parts of the backward part of the ball fall down within the first 1-3 years after the treefall. Transferring of the remaining material may continue for tens of years.

Crumbling of the material into the pit can alternate with an influx of new portions of litter. The influx of litter and peculiarities of its accumulation largely depend on the flora composition, moisture conditions in the pit and properties of the soil. Under normal moisture, rich composition of the litter and pedofauna activity may result in a faster accumulation of humus in the pit comparatively to the surrounding soil. At excessive moisture in the pit, there can be formed a pool, which accumulates humus or peat.

\section{Patterns of treefall-related pedoturbations}

In the soil profile, a pit-and-mound pair looks as a complex of pedons, which are homogenous sets of sections of soil horizons with the characteristic soil patterns (Fig. 2, 3).

The horizontal spread of such a complex ranges from 1 to 10 and more meters (most often 2-4 meters). A complex of pedons is characterized by alternating soil sections which differ in the depth of transitional horizons, pronouncedness of contrast, differently colored horizons, etc. The spread of a single pedon ranges from several centimeters to several meters. 


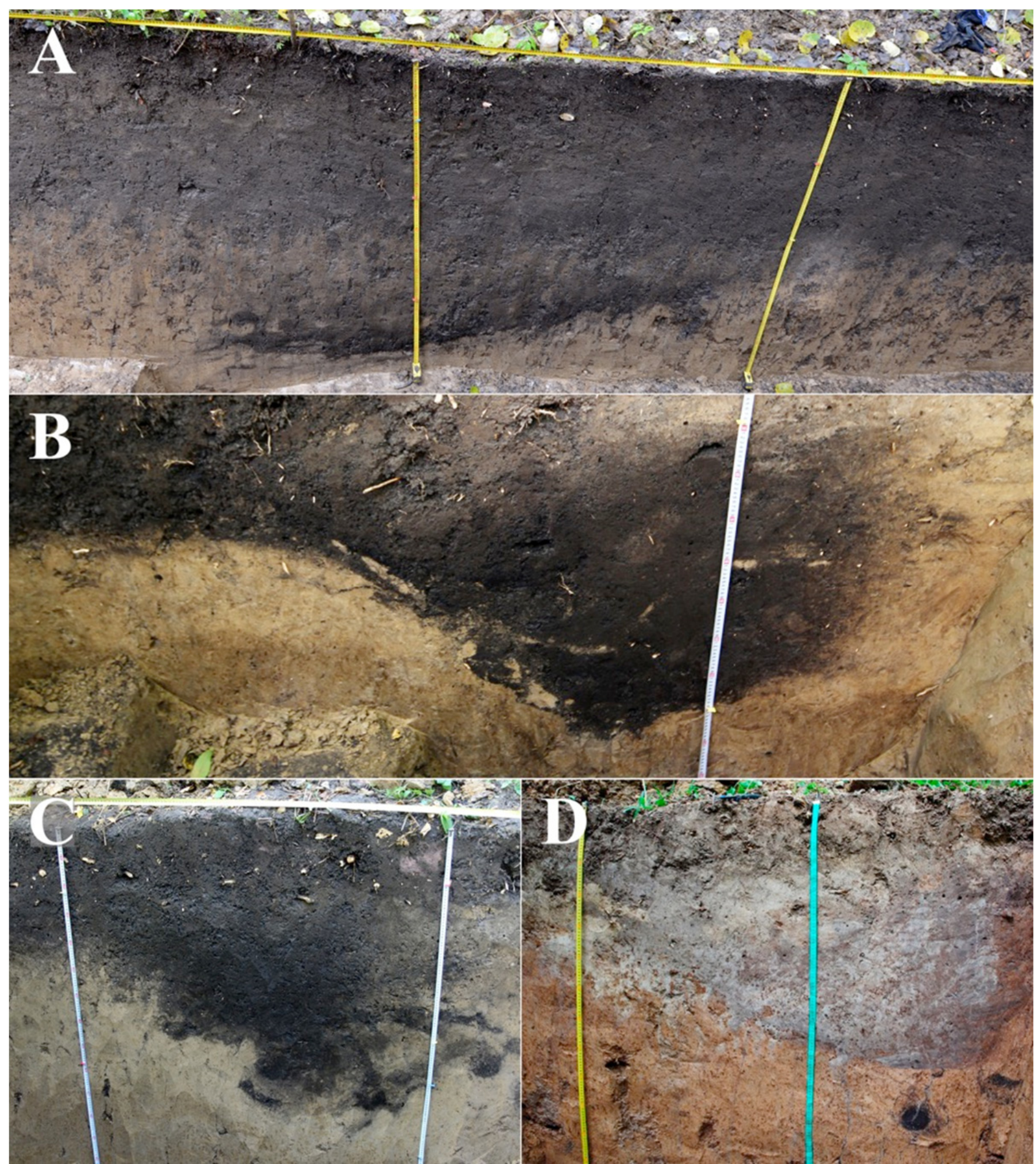

Fig. 4. Patterns of old pits (cauldrons) caused by rotational treefalls in the soil profiles: A - Luvic Stagnic Phaeozem (Tomsk region); B, C - Luvic Phaeozems (Kaluga region); $D$ - Albic Luvisol (Kaluga region)

It is easier to distinguish a treefall pattern in the soil as long as the pit-and-mound topography is preserved on the surface. Most authors evaluate the maximum age of pit-and-mound topography (the period while the mound and pit formed by a treefall are visible) as hundreds and sometimes a few thousands of years (see review in [8]). However, the subsequent pedoturbations destroy the pit-andmound topography. It can be natural pedoturbations (first of all, the subsequent treefalls) and various human impacts. For example, destruction of pit-andmound topography in many regions was long related to pasturing (including forest pasturing), slash and burn clearing, agriculture, etc. Disappearance of the microrelief will be especially rapid in overmoistened soils, as a result of sliding of overmoistened soil material into the pit. Studies conducted in the "Black" ("Chern") taiga in the Western Siberia indicate that within 15-30 years, the depth of treefall pits decreases from $50-70$ to $5-15 \mathrm{~cm}$. 
Nevertheless, treefall signs can be seen in soil profiles even after destruction or alteration of upper soil horizons. What we see upon examination is, in fact, a pattern of soil material in the pit of the treefall complex. As shown above, this material is not homogenous; it consists of different homogenous parts (portions). These are portions of material which was transferred upon rotation, crumbling or washing-out. On a cross-section, we see complexes of patches (i.e., a soil profile pattern consists of a complex of spots or patches, see Fig. 4). A patch is a section of a $3 \mathrm{D}$ pattern fragment (i.e., a patch is a homogenous spot in the profile). The size of patches can range from several millimeters to several centimeters; sometimes, the length of a patch exceeds one meter.

On a large scale, we see a print of a pit filled with soil material (a specific soil pattern) and some structures allowing one to determine the boundaries of the treefall-related pedoturbation (see below). In the vertical projection, the shape of pits varies from that of a saucer or bowl to almost rectangular (Fig. 1, 2). In the horizontal projection at any depth, pits usually have an oval/elliptic shape. Parts of a pit can be separated, to a varying extent, from the "background"/surrounding soil. For the shape of the entire pit to be visible, the length of the soil profile (trench) should be several meters (usually from 3 to $10 \mathrm{~m}$ ). Besides, the trench can dissect the pit in any direction, and not necessarily in the direction of the treefall, as it is shown in Fig. 1, 2. On the vertical walls of customary sized soil profiles we see only fragments of treefall-related pedoturbations.

On a medium scale (tens of centimeters), we can see blocks (large lumps) as large patches or complexes of patches specific for different parts of the pit: organic matter or humus in the frontal part of the pit and at the bottom of the backward part of the pit of rotational treefall complexes; large spots of lightened (as a result of gleization) material in the pits, etc.

On a small scale (up to several centimeters) we see a mosaic of small patches: rounded and streaky structures, which are a result of sedimentation and transfer of soil material in various proportions.

The structure and the degree of inhomogeneity of the pit material mainly depend on the following factors:

1) character of the soil material before the treefall including the extent of differentiation of soil horizons by their color and structure;

2) character and intensity of transformation of material in the process of formation of the treefall complex (transfer, mixing, etc.);

3) peculiarities of transfer of the root ball material after the treefall: rate of crumbling, size of crumbled material portions and intensity of erosion;

4) processes taken place in the soil profile after the treefall: e.g., erosion, leaching, gleization, etc. including processes initiated by anthropogenic impacts on the upper soil layer. In loamy soils (Albeluvisols, Luvisols), leaching, which is especially intensive upon ploughing, can substantially mask the patterns of treefall-related pedoturbations.

For preservation/destruction of treefall-related soil patterns, of great importance are subsequent pedoturbations, such as growth of roots and formation of root channels, subsequent treefalls, activity of pedofauna (first of all, earthworms and vertebrate burrowers) and various anthropogenic impacts.

Listed below are the most frequent variants of patterns formed as a result of treefall-related pedoturbations in forests.

1. Treefall pits (cauldrons). They can be seen in trenches and wide profiles of the soils that have horizons with the materials of contrast colors within the limits of the average depth of treefalls. Mixing of these materials result in formation of a mosaic of patches, which differ by their structure from the surrounding horizons. Their sizes correspond to the sizes of treefall pits. Morphogenesis of polymorphones-cauldrons has two components: (1) filling the pit with the unchanged material from the root ball and the pit walls in various combinations and sequences; (2) alteration of the soil mass of the treefall complex by a group of processes of increased intensity in comparison with the adjacent unperturbed soils (destruction of aggregates, separation and washing of particles, gleization). Through these processes, there appear morphological elements, which are absent or not so evident under background conditions.

2. Spotty or streaky structures from the material of a different degree of contrast, including single lumps/spots, are the most frequent component of treefall-related pedoturbations (Fig. 5).

Spottiness mainly forms as a result of $(a)$ crumbling of the material of different color (for example, from different parts of the ball) and (b) layering of sediments in the process of erosion/water transport of the material.

Sandy soils are mostly characterized by distinct, rounded patches (Fig. 5,A,B). Depending on the contrast of the initial material, we can see patterns varying from evident, sharp patches to blurred, vague «marble-like» structures. In homogenously colored sandy soils, such spottiness can be very faint, but usually it is distinguishable on some segments of the soil profile. 


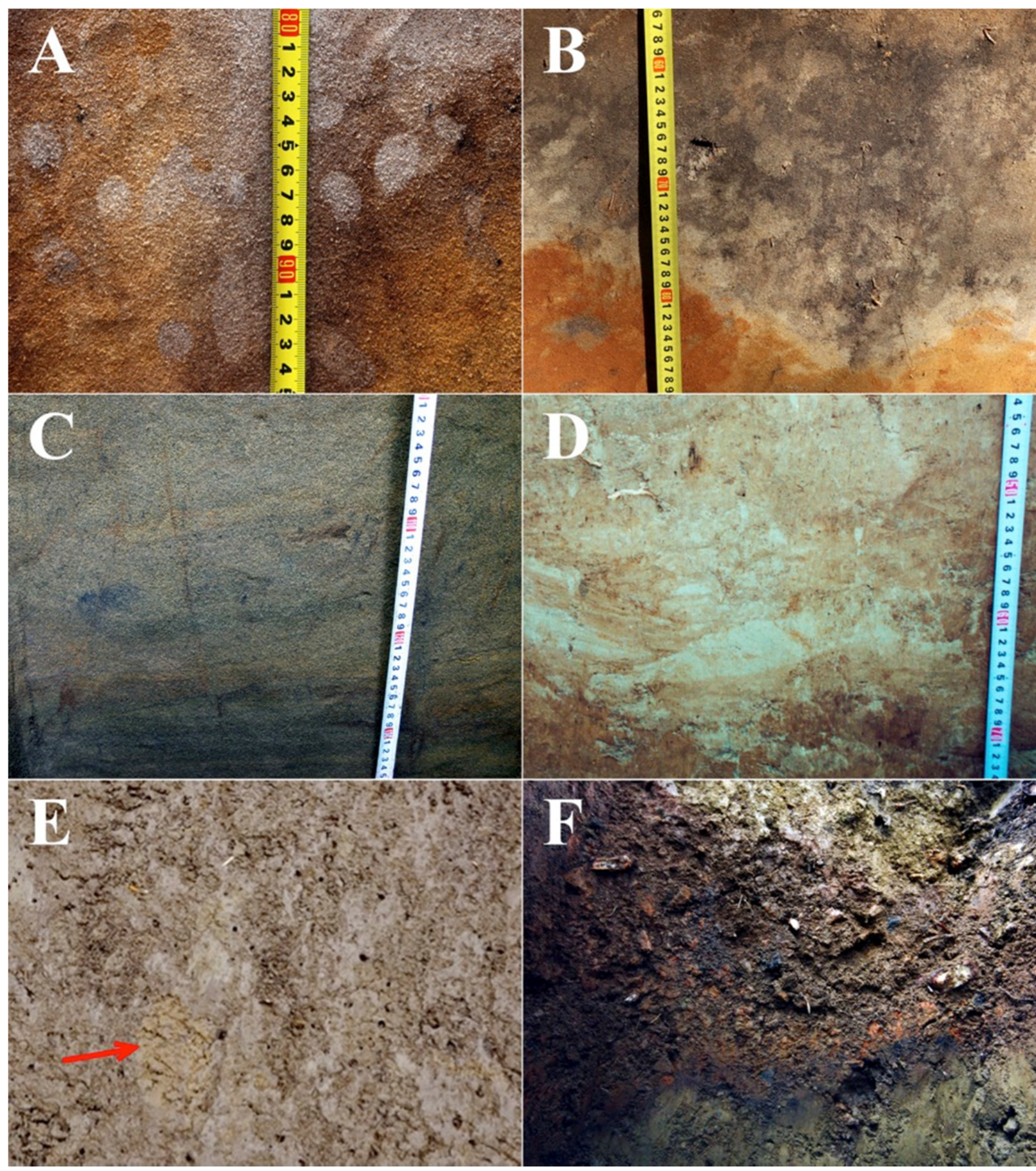

Fig. 5. Spotty or streaky structures caused by treefalls in the soil profiles:

A - Haplic Podzol, depth 80-95 cm (Kaluga region); B - Entic Podzol, 60- 90 cm (Kaluga region); C - Entic Podzol, 100- 135 cm (Krasnoyarsk region); D - Albic Luvisol, 45-70 cm (Kaluga region); E - Albic Stagnic Luvisols, 30-35 cm (Tomsk region); F - Histic Umbrisol, 20-60 cm (Caucasus Mountains, Krasnodar region)

Loamy soils are characterized by more frequent occurrences of streaky structures (Fig. 5,D). They form when a portion or a few portions of the material fallen from the root ball are separated with a streak of another material. The streak can be formed as a result of transformation of the material at the spot (under the effect of raindrops, cycles of freezing/thawing, influx of litter, etc.) and/or under the influx of the eroded material.

The lesser the cohesion of the crumbling material, the more flattened layers are formed.
There can be formed relatively large patterns, which in a small soil profile will be seen as a separate specific horizon. A specific case is the formation of outlier structures [52-54], in which a dull and light material of the albic (E) horizon is impregnated with heavier brownish lumps (outliers) of the agric $(\mathrm{Bt})$ horizon. Formation of such structures is considered to be associated with the outlier and eluvial-texture forms of soil degradation $[53,55]$. We believe that this pattern is formed as a result of regrouping of the soil material by tree 
uprooting, when fragments of the agric horizon alternate with the light-material layers in the pit.

A specific case is also the occurrence of single, isolated lumps/spots originating from crumbling of single lumps contrast to the basic crumbling material. As a result, the upper or middle part of the profile can contain lumps/spot of the material of deep horizons (Fig. 5,E,F). For example, it may be inclusions of loam lumps in sandy horizons in two-component soils, in which a layer of sand lies upon loam.
3. Blocks of "buried material" (Fig. 6). As discussed above, the frontal part of the pit of rotational treefall complexes is a special depot for the material of upper horizons. It is especially evident when the pit contains sediments which are relatively large blocks of the albic (Fig. 6,A) or humus (Fig. 6,C,D) horizons. In this case, we see "buried" fragments of those former horizons in the middle or even lower horizons of a soil profile.

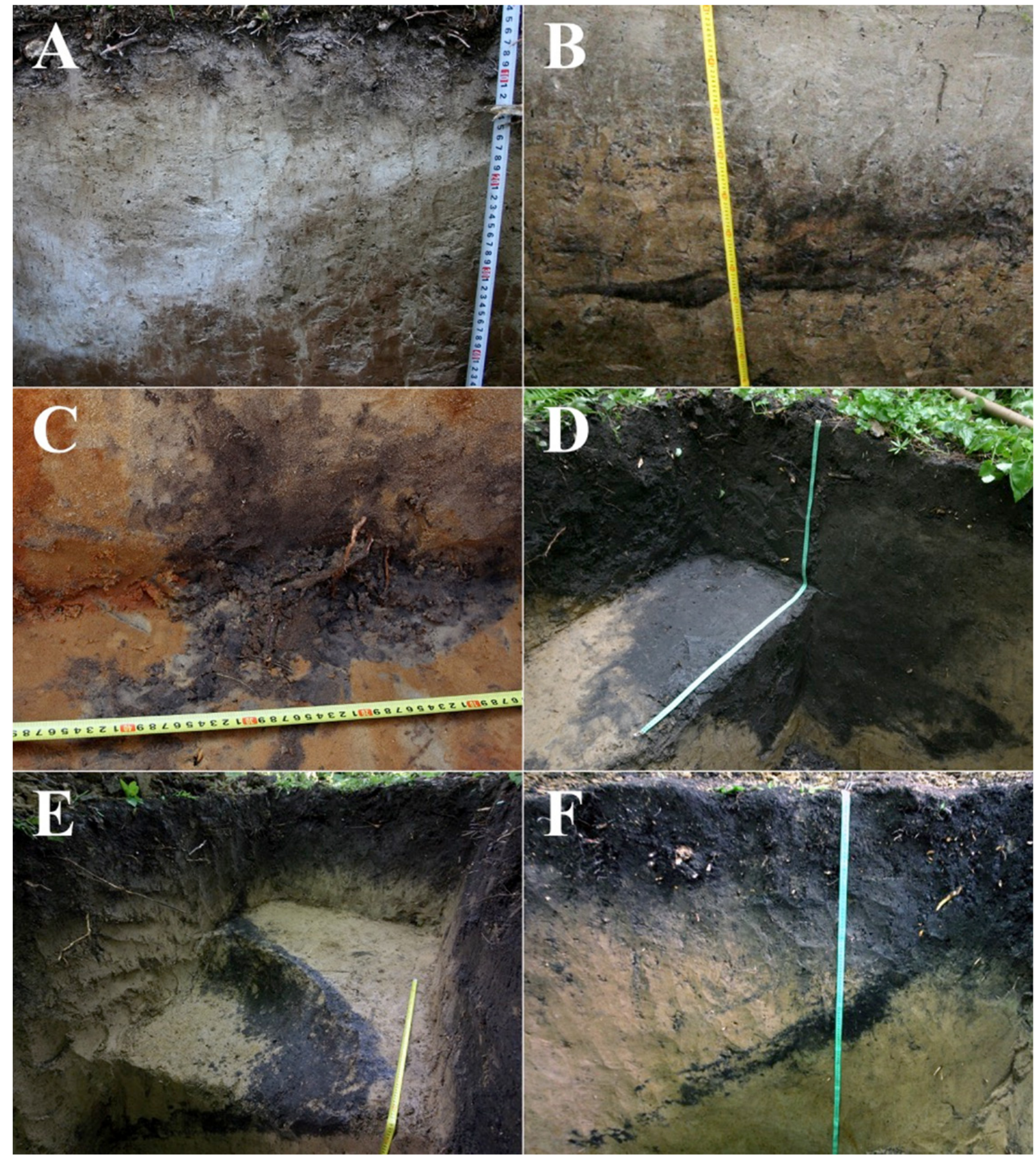

Fig. 6. Blocks of albic $(A)$ and humic $(B-F)$ "buried material" in the old pits caused by rotational treefalls: $A$ - the front part of the pit, depth $20-40 \mathrm{~cm}$, Haplic Albeluvisol (Vologda region); $B$ - the back part of the pit, 85-100 cm, Albic Luvisol (Tomsk region); $C$ - the front part of the pit, 85-105 cm, Entic Podzol (Kaluga region); $D$ - the front part of the pit, 40-120 cm, Luvic Phaeozems (Kaluga region); E, F - the back part of the pit, 40-100 cm, Luvic Phaeozems (Kaluga region) 
When a humified material is transferred into the back part of the pit of rotational treefalls, specific patterns are formed. The material is layered at the bottom of the bowl-shaped pit; in the profiles they look like sloping layers or spot complexes (Fig. 6,E,F).

Sometimes, large blocks of "buried material" look like inverted horizons in a section of the pit (within a pedon).
4. Washed (bleached) material (Fig. 7, 8). As discussed above, for some time, a root ball and a pit together are a zone of erosion with soil matter detachment, transport and deposition. As a result, a light pulverescent material deposits at the bottom of the pit and fills cylindrical soil pores and channels of various origins (root channels, earthworm holes, fissures, etc.). The bleaching occurs due to an outflow of silt and fine-pulverescent fraction.

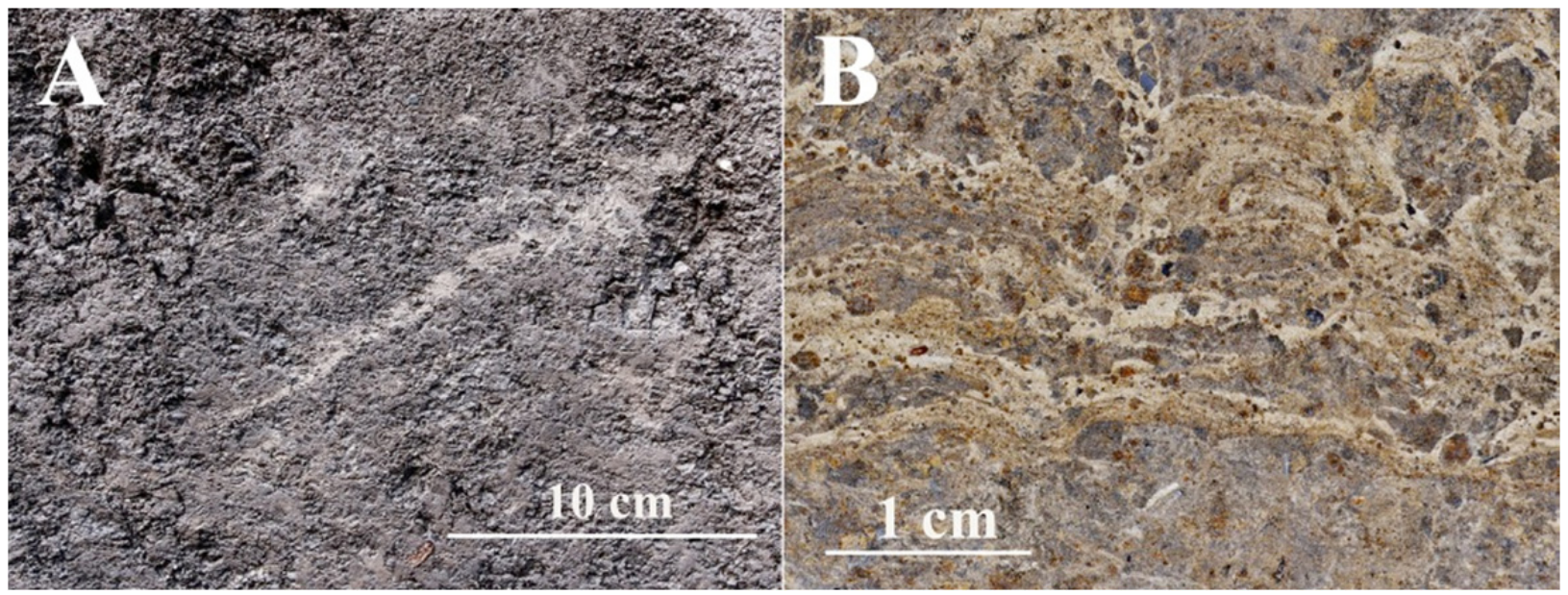

Fig. 7. Washed (bleached) coarse-grained sediments in the old pits caused by treefalls of Abies sibirica: A - Luvic Stagnic Phaeozem (Endoclayic), depth 25-35 cm; B - Luvic Stagnic Phaeozems (Clayic), 45-50 cm (both in Tomsk region)
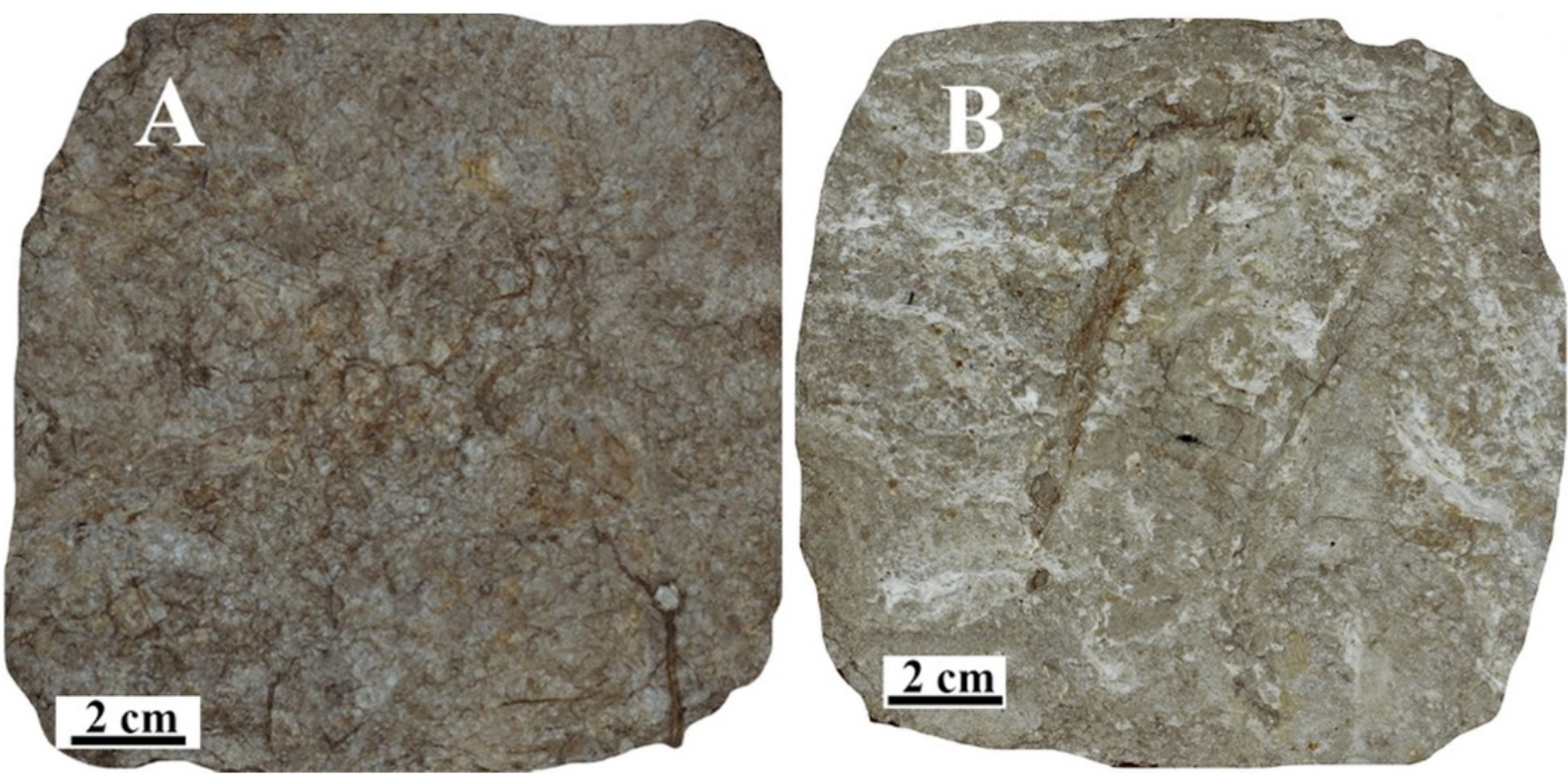

Fig. 8. Soil fragments from neighbour plots in the same depth:

A - background soil without treefall signs; B - streaky structures by coarse-grained sediments in the old pit caused by treefalls of Abies sibirica (Tomsk region)

These structures are hardly distinguishable from common coarse-grained infillings in the Bt horizon. In contrast to common sediments of the root ball, these structures have a lighter granulometric composition than the surrounding soil. They consist of conglomerates of pulverescent mass, as well as aggregates with preserved, unbleached core. The content of silt fraction in the bleached material is on average 1.9 times less than its content in the surrounding soil [43].

5. Signs of hydrogenous changes of soil material (gleization). The pits often form conditions for more or less prolonged excessive moisture. Stagnation of water (excessive moisture) can be seasonal or long- 
term (multi-year). Water will stagnate in the pit especially long when the lower part of the soil profile is heavier than the upper part and less permeable to water and the bottom boundary of the pit lies within this heavy part. An example is the cemented horizon spodic (Bhs) in Podzols or the dense horizon argic (Bt) in Albeluvisols or Luvisols.

Signs of over moisture look as separate areas of accumulated ferric hydroxides, gley spottiness and stains of unstructured material (Fig. 9).
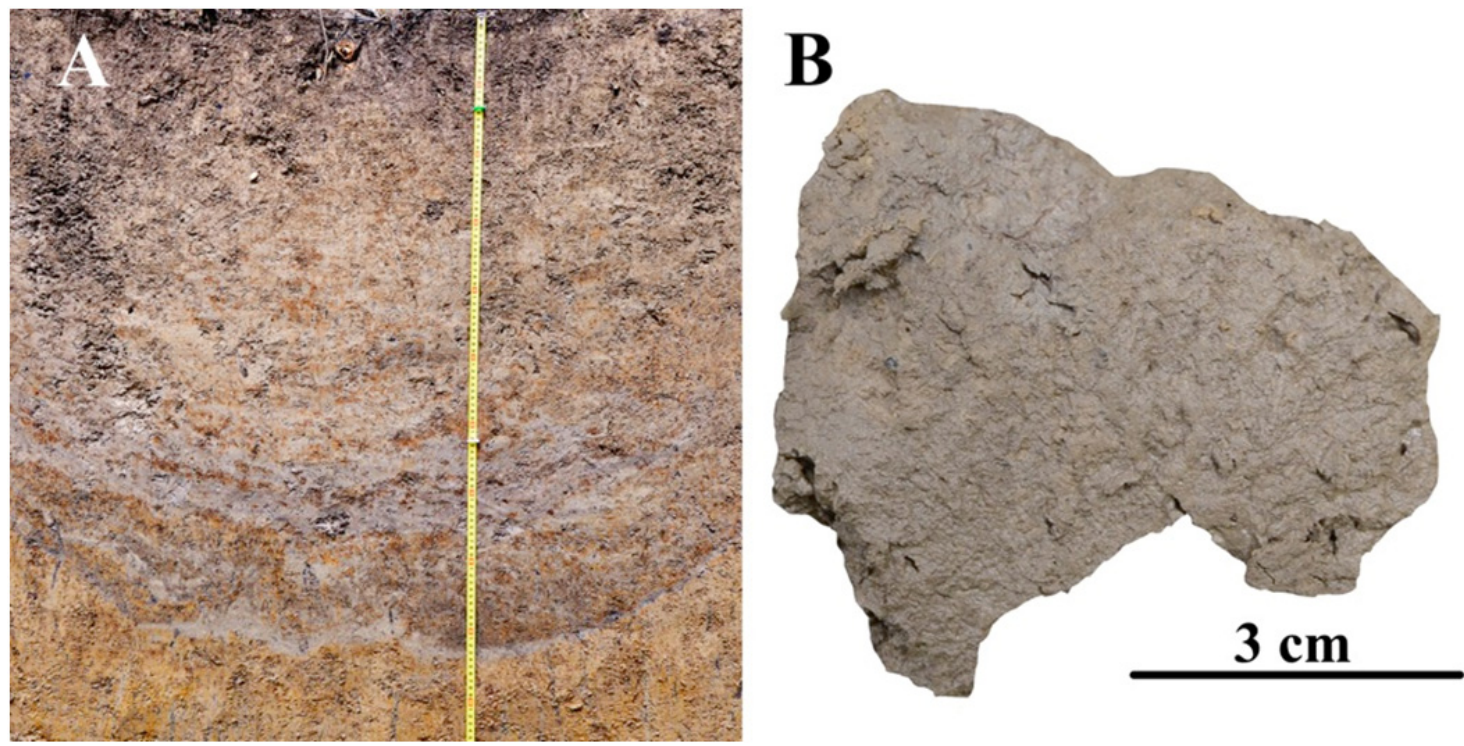

Fig. 9. Hydrogenous changes of soil material:

A - gley matter in the old (60-70 years old) pit caused by rotational treefall; $B$ - structural degradation of soil aggregates because of gleization in the pit. Both Albic Stagnic Luvisol (Endoclayic, Episiltic), Tomsk region

Even at a relatively short seasonal excessive moistening of sediments, brownish/rusty patches with an increased content of ferric hydroxides are formed in the lower part of the pit. One of the sources of iron is the litter falling into the pit. In Luvisols, the iron content in such patches is 1,2-1,6-fold of that in the surrounding soil [43].

More prolonged moistening results in spottiness: rusty-ochreous and bluish patches of pseudogley are formed. We observed cases when during one season, bluish gley layers several centimeters thick were formed in the pits on loamy soils. Such structures are common in semi-hydromorphic and hydromorphic soils; in the profiles of automorphic (non-hydromorphic) soils, they can be found locally, usually in the old pits. The area of such a pattern can be a few hundred $\mathrm{cm}^{2}$.

With long-term stagnation of water in loamy soils, soil aggregates may be subjected to desilting and to structural degradation because of gleization. As a result, sediments in the pit look like large spots of light (leucinizated) dense material (Fig. 9,B).

Similarly, large podzol spots can be formed in the pits of treefall complexes on sandy soils, with ironpoor areas being often adjacent to iron-rich orsteins. In well-drained sandy soils, sings of over moisture are absent, so it is difficult to diagnose the bottom boundary of a pit if the soil was perturbed by treefalls many times. The pit boundary of a single treefall complex is diagnosed by the border of a spotty pattern and the texture of natural parent rock.

6. Root channels associated with the bottom boundary of a pit are additional evidence of its origin from a treefall with uprooting (Fig. 10). After pulling out the roots, the root channels in the soil are quickly filled with the material above them. Thin root channels are characterized by a more homogenous filling. The channels formed by large (thick) roots can contain large pieces of crumbling material fallen from above, with the spaces between them filled with deposited (partially lightened) material transported with water.

Some roots leave their parts in the soil after snapping. The material of the root channel is partly humusified, and partly formed by the crumbling material of the upper soil layers. The color of such former roots left in the soil will depend on both the properties of the tree wood and the composition/color of sediments.

Under hydromorphic conditions, the color is determined by ferric and manganese hydroxides: the root channels have brownish, ochreous tones (Fig. 10,A). The material of the root systems is often utilized in the process of formation of orsteins, rorensteins and other mangnesium and iron concretions.

Peculiarities of root channels formation and their filling upon the death of various tree species is a separate topic to discuss (see [18]). 


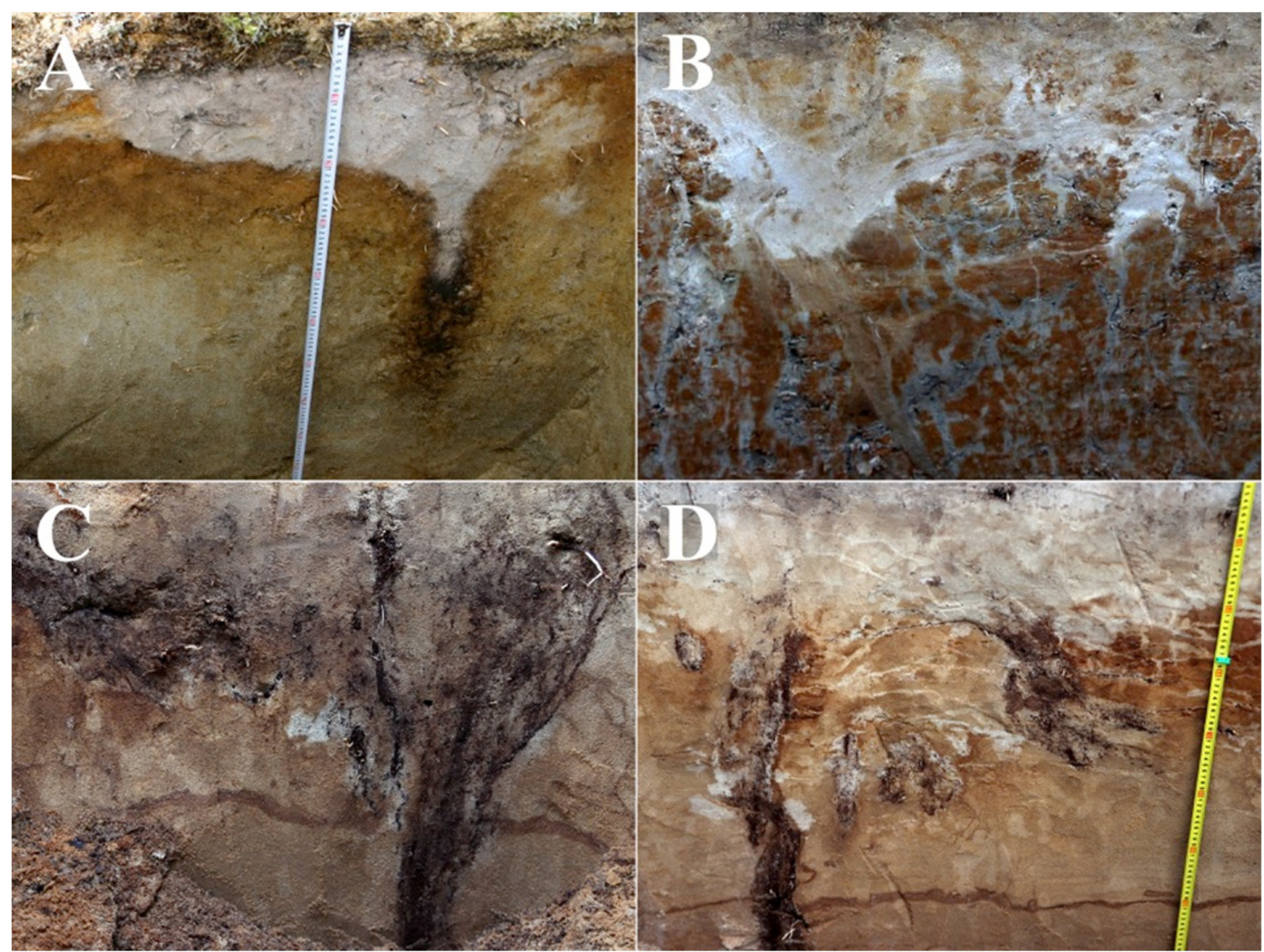

Fig. 10. Root channels with different deposits associated with the bottom boundary of the old pits: A - Haplic Podzol (the Komi Republic); B - Albic Luvisol (Clayic) (Tula region); C, D - Entic Podzol (Ryazan region)

7. Inclusions (litter and charcoal). The presence of buried litter or charcoal in a soil profile is usually a result of a treefall-related pedoturbation (Fig. 11). In case of hinge treefalls, litter and charcoal turn out to be buried under the frontal part of the mound like any other material of the upper soil layer. In case of rotational treefalls, they are usually buried in the frontal part of the pit. Under these circumstances, charcoal pieces can form layers or large aggregates in the soil. Charcoal pieces can also be scattered in the soil profile, if their number is not large or if the soil was perturbed by treefalls more than once. Locations of charcoal pieces relative to treefall pits enables one to determine periodicity of fires [56-58] and to date a time of treefall $[31,59]$.

Many authors point out the uneven distribution of buried charcoal pieces over the profile depth: a part of them are in the upper layer and another part, at a depth of $40-80 \mathrm{~cm}$ and more [60, 61]. Such a gap in distribution of charcoal pieces over the profile depth can be explained by differences in the ways of charcoal burying into the soil. Charcoal pieces would lie shallow if they were buried as a result of ploughing or pedofauna activity. If charcoal was moved by a treefall, it would mainly be accumulated at the pit's bottom. The predomi- nant depths of charcoal occurrence $(40-80 \mathrm{~cm})$ correspond to the prevailing depths of treefall pits (see Table above). The results of our studies of silt infillings in Luvisols showed that charcoal pieces could be transported with water at a depth of more than a meter, yet the size of such pieces would not exceed $0,2 \mathrm{~mm}$.

Understanding relationships between the distribution of charcoal pieces in soil and the ways of their transfer in soil profiles is crucial for pedoanthracological studies [57, 62-65, etc.] and it is a topic for separate discussion.

\section{Types of soil profiles depending on features of treefall-related pedoturbation patterns}

A serious problem impeding recognition of the role of treefalls in formation of forest soil profiles is that most authors have regarded traces of old treefalls in soil profiles as occasional findings. Treefall-related pedoturbations have been considered as a common and sometimes even mass but not ubiquitous phenomenon. Meanwhile, every plot of soil cover in the forest region was perturbed by treefalls time and time again. 


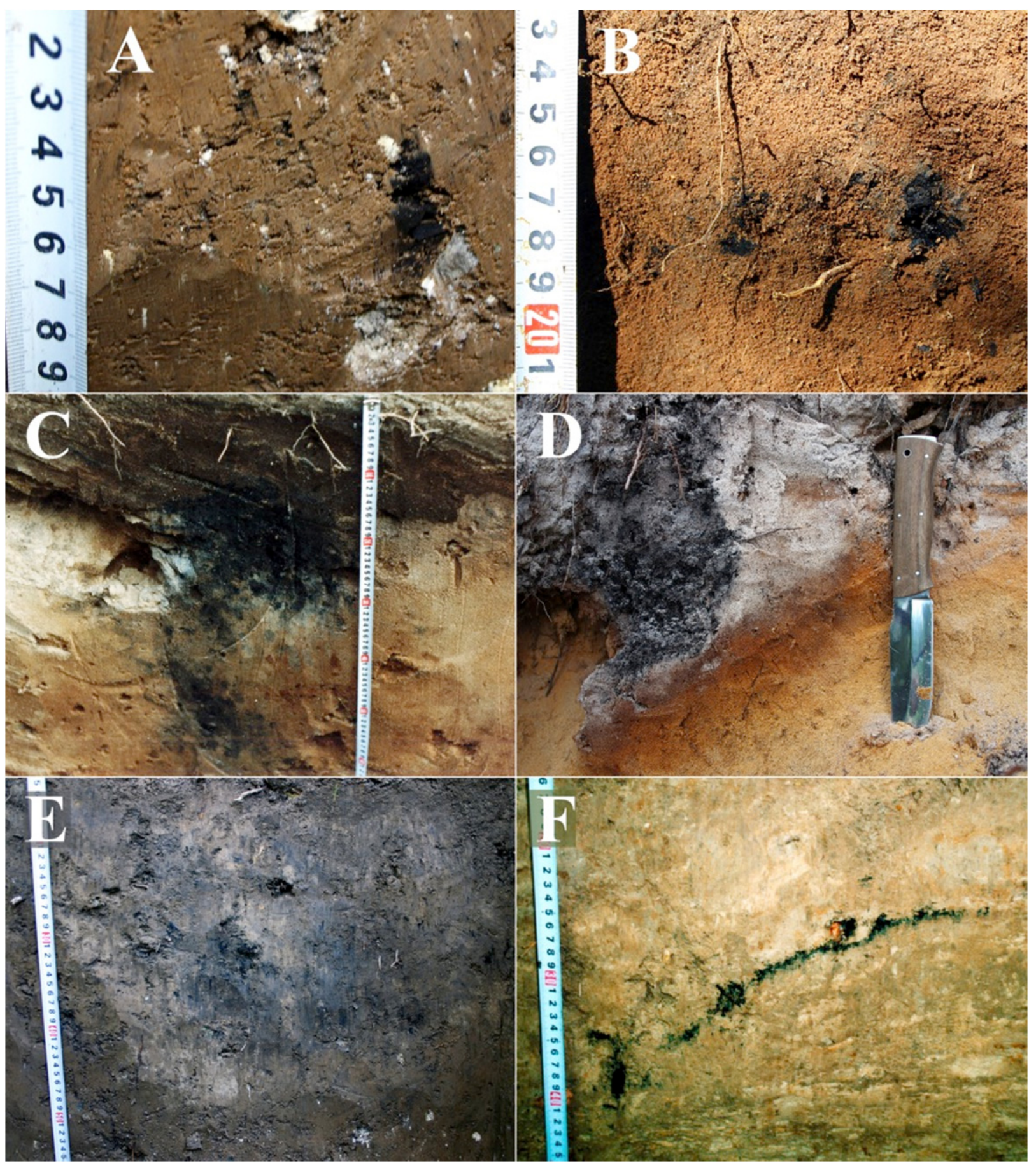

Fig. 11. Charcoal displaced by treefalls in the soil: single $(A, B)$, aggregation $(C-F)$ and "buried layer": A - Calcic Luvisol (Vologda region); B - Entic Podzol (Krasnoyarsk region); C - Brunic Arenosol (Kaluga region); D - Haplic Podzol (the Komi Republic); E - Albic Luvisol (Vologda region); F - Haplic Fluvisol (Kaluga region)

In general, the middle and lower parts of profiles of most forest soils represent patterns originating from the transfer of soil material upon treefalls.

We distinguish several basic variants of structure of forest soil profiles defined by features of their treefall-related pedoturbation patterns $[21,47,66]$. The latter depends on the combination of two factors: the first, soil granulometric properties affecting the transfer of soil material (sedimentation, erosion and leaching) and the second, variants of the ecosystem history.
The main types of soil profiles specified by their treefall-related pedoturbation patterns are the following:

1. Treefall-related pedoturbations occur within a relatively thick homogenous horizon, presumably humus $(A)$ or histic $(H)$ horizons, and the traces of pits are partially erased by the pedofauna activity. The depth of single treefall complexes exceeds the thickness of the humus horizon (Fig. 4, $A-C, 6, D-F$ ). Such profiles are common for Cambisols, Phaeozems and Umbrisols, as well as for some Entic Podzols (podburs) and Histosols. 
2. Old pits are partially masked by lessivage and transfer of soil material along the root channels (Fig. 4,D, 6, $A, 12, A, B$ ). Such patterns are characteristic for areas where free forest development alternated with cutting and ploughing and transfer of soil material by tree falls with uprooting alternated with erosion and leaching. The patterns are typical for the profiles of loamy soils in hemiboreal and temperate forests (first of all, Albeluvisols and Luvisols) including soils with second humus horizon. Superposition of two patterns (the pattern related to formation of root channels and the treefall-related pattern) indicates that during the last centuries, life of trees was disrupted by cuttings and did not end with treefalls (Fig. 12,B).

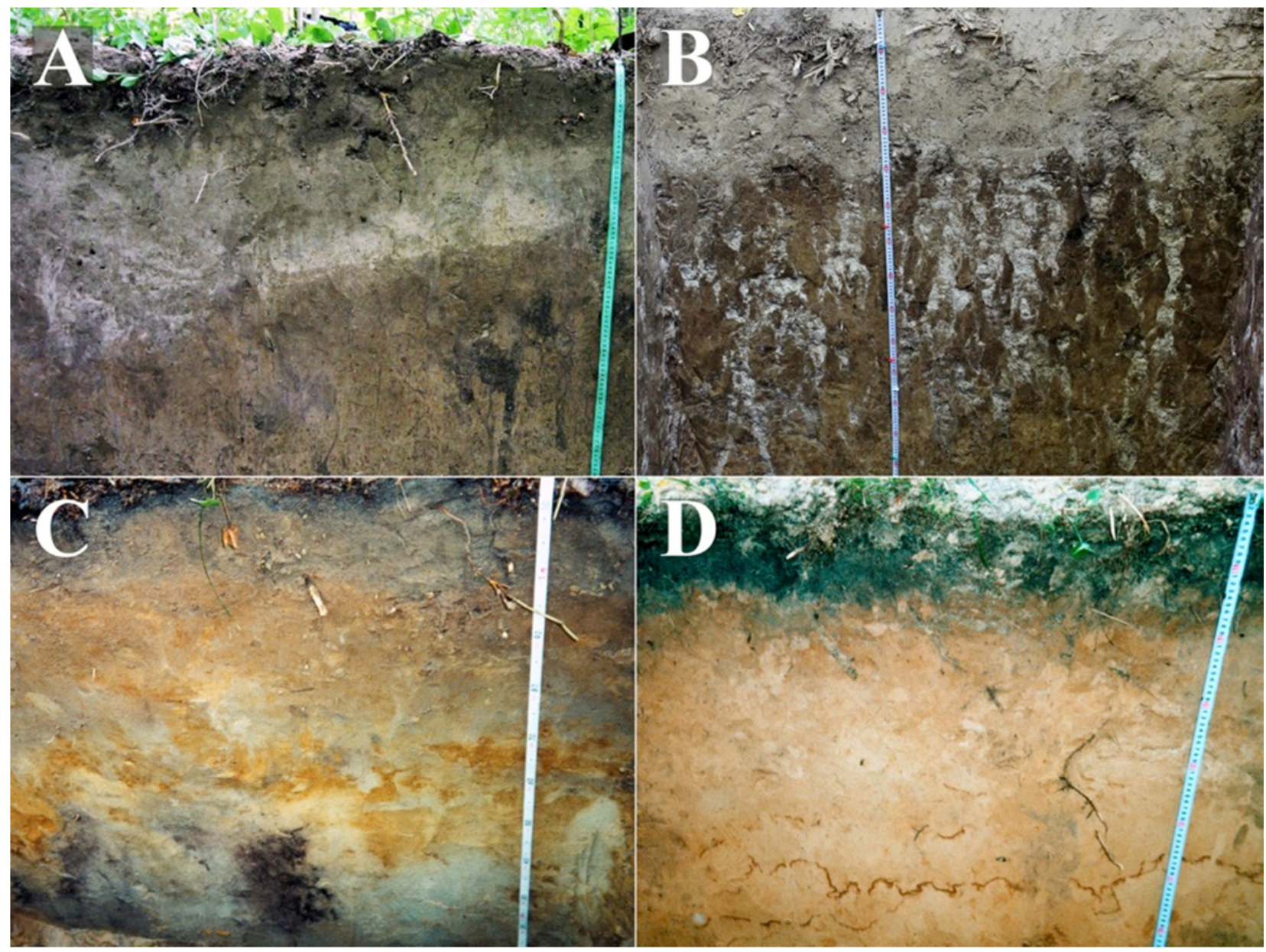

Fig. 12. Soil profiles with patterns of treefall-related pedoturbations (Kaluga region):

A - Albic Luvisol; B - Haplic Albeluvisol; C -Brunic Arenosols (Endogleyic Nechic); D - Brunic Arenosols (Nechic)

3. Profiles with mosaic structure consist of patches of contrasting colors in old pits (Fig. 6,C, $12, C)$. They are mostly common for sandy soils, first of all, various Podzols. Contrasting colors often result from the transfer of soil material of the upper horizons $(\mathrm{E}, \mathrm{A}, \mathrm{H})$ during the treefalls, as well as from soil metamorphic processes in the pits. Sometimes, the color changes due to staining of mineral particles by disperse charcoal.

4. Profiles in which traces of old pits are hardly discernible for treefalls transferred non-contrasting material (Fig. 12,D). They are mostly common for poor sandy soils. The traces of pits can be diagnosed by spotty and streaky structures, charcoal inclusions, etc.

5. Traces of old treefalls are absent. This is usually observed in highly eroded soils.

\section{Conclusion}

In the forest zone, treefalls are the most powerful and ubiquitous biotic factor changing the structure of soil profiles. So far, numerous investigations of structure and dynamics of treefall-related soil complexes have not led to cardinal changes of the theoretical views of soil science. One of the main causes probably consists in the study of "contemporary" treefalls, traces of which in the form of pit-and-mound topography are still preserved. As a rule, the pits of old treefalls in soil are not discerned by researchers.

The results of our studies confirm the data of other authors $[9,18,26]$ that the traces of old pits and the material inside them can be preserved for unlimited time; they are only erased by the subse- 
quent pedoturbations. A common situation is when a part of a pit pattern is preserved and another part is erased by later impacts (treefalls, root channels, activity of burrowers, ploughing, etc.) As pointed out by Skvortsova et al. [9], it may be difficult for a soil scientist to admit possible treefall-related pedoturbations in case of one or two «normally» formed upper horizons; it is despite the fact that the structure of the lower part of the profile reveals an anomaly. However, practically every profile has a number of anomalies which are within the limits of the potential depth of treefall-related pedoturbations and in most cases, these anomalies are indeed a result of treefalls. Researchers either tend to treat these anomalies as "white noise" (relating, for example, inhomogeneities in the structure of continual $\mathrm{Bt}$ and Bhs horizons to unevenness of illuviation) or consider their causes to be beyond soil science (describing them, for example, as a result of geological processes). In archeological works, old treefall pits are often described as "pits of regular shape", and their origin is ascribed to "a human activity of unknown purpose" $[67,68]$; see discussions in $[25,41,69]$.

Meanwhile, analysis of a soil profile within the forest region should be based on the assumption that its material was transferred by treefalls or other biogenic pedoturbations and it, perhaps, took place repeatedly. It should be also taken into account that pedoturbations could affect the profile at a depth larger than the depth which is usually described by the soil horizons A, E, Bhs, etc.

Discerning in soils of old treefall-related patterns significantly alters our understanding of the forest soil formation and leads to the necessity of a serious correction of pedogenesys concepts.

\section{Acknowledgements}

This work was partly supported by the Russian Foundation for Basic Research, Projects 14-34-50140 and 15-04-03170 and the Russian Federation President Grant MK-6317.2015.4.

\section{References}

1. Denny C. S., Goodlett J. C. Microrelief resulting from fallen trees. Surficial Geology and Geomorphology of Potter Country, Pennsylvania. US Geol. Surv. Prof. Pap. 1956, vol. 288, pp. 59-68.

2. Stephens E. P. The uprooting of trees - a forest process. Proc. Soil Sci. Amer. 1956, no. 11, pp. 113-116.

3. Lyutsau S. V. On the role of woody plant systems in shifting of mellow fragmental masses on slopes and in relief formation. Problems of geography. Moscow: State publishing of geographical literature, 1959, vol. 46, pp. 169-177.

4. Lutz H. T. Movement of rocks by uprooting of forest trees. Amer. J. Sci. 1960, no. 10, pp. 752-756.

5. Dmitriev E. A., Karpachevsky L. O., Stroganova M. N., Shoba S. A. On the origin of soil cover heterogeneity in forest biocenoses. Problems of pedology. Moscow: Science, 1978, pp. 212-218.

6. Karpachevsky L. O., Dmitriev E. A., Skvortsova E. A., Basevich V. F. The role of treefall in formation of soil cover structure. Soil cover structure and soil resources management. Moscow: Science, 1978, pp. 37-42.

7. Dmitriev E. A., Karpachevsky L. O., Skvortsova E. B. The role of treefall in formation of soil cover in forests. Genesis and ecology of soils of the Central-forest state reserve. Moscow: Science, 1979, pp. 111-120.

8. Basevich V. F. Pedoturbations during treefall and their role in formation of soil cover of forest biocenoses: author's abstract of dissertation to apply for the degree of the candidate of biological sciences. Moscow, 1981, $24 \mathrm{p}$.

9. Skvortsova E. B., Ulanova N. G., Basevich V. F. Ecological role of windfalls. Moscow: Forest industry, 1983, 192 p.

10. Beatty S. W. Influence of microtopography and canopy species on spatial patterns of forest understory plants Ecology. 1984, vol. 65, pp. 1406-1419.

11. The Ecology of Natural Disturbance and Patch Dynamics. Ed. by S. T. A. Pickett, P. S. White. San Diego: Academic Press, 1985, 472 p.

12. Beatty S. W., Stone E. L. The variety of soil microsites created by tree falls. Agron. Pap. 1986, vol. 1406, pp. 539548.

13. Schaetzl R. J., Burns S. F., Jonson D. L., Small T. W. Tree uprooting: review of impact on forest ecology. Vegetation. 1989, vol. 79, no. 3, pp. 165-176.

14. Schaetzl R. J., Jonson D. L., Burns S. F., Small T. W. Tree uprooting: review of terminology, process, and environmental implication. Canad. J. For. Res. 1989, vol. 19, no. 1, pp. 1-11.

15. Schaetzl R. J. Effects of treethrow microtopography on the characteristics and genesis of Spodosols, Michigan, USA. Catena. 1990, vol. 17, no. 2, pp. 111-126.

16. Hytteborn H., Liu Q., Verwijst T. Natural disturbance and gap dynamics in a Swedish boreal spruce forest. Coniferous forest ecology from an international perspective. Ed. by N. Nakagoshi, F. B. Golley. Hague: SPB Academic Publishing, 1991, pp. 93-108.

17. Kuuluvainen T. Gap disturbance, ground microtopography, and the regeneration dynamics of boreal coniferous forests in Finland: a review. Ann. Zool. Fennici. 1994, vol. 31, pp. 35-51.

18. Ponomarenko E. V. Methodological approaches to analysis of succession processes in soil cover. Succession processes in reserves of Russia and problems of biological diversity preservation. Edited by O. V. Smirnova, E. S. Shaposhnikov. Saint-Petersburg: RBS, 1999, pp. 34-57. 
19. Ulanova N. G. The effects of windthrow on forest at different spatial scales: a review. For. Ecol. Manage. 2000, vol. 135, pp. 155-167.

20. Bolysov S. I. Biogenic relief formation on dry land. Moscow: Geos, 2007, vol. 2, Zonality, 466 p.

21. Bobrovskii M. V. Forest soils of European Russia: biotic and anthropogenic factors of formation. Moscow: Partnership of scientific publications KMK, 2010, 359 p.

22. Armson K. A., Fessenden R. J. Forest windthrow and their influence on soil morphology. Soil Sci. Soc. Am. Proc. 1973, vol. 37, pp. 781-783.

23. Schaetzl R. J., Burns S. F., Small T. W., Johnson D. L. Tree uprooting: review of types and patterns of soil disturbance. Phys. Geogr. 1990, vol. 11, pp. 277-291.

24. Allen J. R. L. Trees and their response to wind: mid Flandrian strong winds, Severn Estuary and inner Bristol Channel, southwest Britain. Philosophical Transactions of the Royal Society of London B: Biological Sciences. 1992, vol. 338, no. 1286, pp. 335-364.

25. Langohr R. Types of tree windthrow, their impact on the environment and their importance for the understanding of archaeological data. Helinium. 1993, vol. XXXIII, no. 1, pp. 36-49.

26. Vasenev I. I., Targulyan V. O. Windfall and taiga soil formation (regimes, processes, morphogenesis of soil successions). Moscow: Science, 1995, 247 p.

27. Kramer M. C., Sollins P., Sletten R. S. Soil carbon dynamics across a windthrow disturbance sequence in southeast Alaska. Ecology. 2004, vol. 85, pp. 2230-2244.

28. Samonil P., Král K., Hort L. The role of tree uprooting in soil formation: a critical literature review. Geoderma. 2010, vol. 157, P. 65-79.

29. Mitchell S. J. Wind as a natural disturbance agent in forests: a synthesis. Forestry. 2013, vol. 86, no. 2, pp. $147-157$.

30. Pawlik $€$. The role of trees in the geomorphic system of forested hillslopes: a review. Earth-Science Reviews. 2013, vol. 126, pp. 250-265.

31. Šamonil P., Schaetzl R. J., Valtera M., Goliáš V., Baldrian P., Vašíčková I., Adam D., Janík D., Hort L. Crossdating of disturbances by tree uprooting: can treethrow microtopography persist for 6,000 years? Forest Ecology \& Management. 2013, vol. 307, pp. 123-135.

32. Šamonil P., Daněk P., Schaetzl R. J., Vašičcková I., Valtera M. Soil mixing and genesis as affected by tree uprooting in three temperate forests. European Journal of Soil Science. 2015, vol. 66, no. 3, pp. 589-603.

33. White P. S., Jentsch A. The search for generality in studies of disturbance and ecosystem dynamics. Progress in Botany. Berlin; Heidelberg: Springler, 2001, vol. 62, pp. 399-449.

34. Halle F., Oldeman R. A. A., Tomlinson P. B. Tropical trees and forest: an architectural analysis. Berlin; Heidelberg; New York: Springer-Verlag, 1978, 442 p.

35. Yamamoto S. Gap-phase dynamics in climax forests: a review. Biol. Sci. 1981, vol. 33, pp. 8-16.

36. Hibbs D. E. Gap dynamics in hemlock-hardwood forest. Canad. J. For. Res. 1982, vol. 12, pp. 522-527.

37. Yamamoto S. The gap theory in forest dynamics. J. Plant Res. 1992, vol. 105, pp. 375-383.

38. Remmert H. The mosaic-cycle concept of ecosystems - an overview. Ecol. Studies. Berlin; Heidelberg: SpringerVerlag, 1991, vol. 85, pp. 1-21.

39. Vasenev I. I., Targulyan V. O. A windfall model of taiga soil formation: primary succession. Pedology. 1994, no. 12 , pp. 5-16.

40. Vasenev I. I. Soil successions. Moscow: LKI publishing, 2008, 400 p.

41. Dzięgielewski K. Possibilites of identification and dating of tree windthrow structures on archaeological sites (based on the examples from Podłęze. Site 17). Sprawozdania Archeologiczne. 2007, vol. 59, pp. $393-415$.

42. Bobrovskii M. V., Loiko S. V., Istigechev G. I., Kritskov I. V. Signs of windfalls in dark humic soils of the "Kaluzhskie zaseki" reserve. Bulletin of Tomsk State University. 2012, no. 4 (20), pp. 7-20.

43. Loiko S. V., Bobrovskii M. V., Novokreshchennyh T. A. Signs of windfall morphogenesis of background soils of blackish taiga (by the example of the Tom-Yaysk interfluve). Bulletin of Tomsk State University. Biology. 2013, no. 4 (24), pp. 20-35.

44. Ponomarenko E. V., Ponomarenko S. V., Ofman G. Y., Khavkin V. P. Soil as it is. Nature. 1993, no. 3, pp. 16-26.

45. Bobrovskii M. V. Windfall disturbances in the soil cover of the "Kaluzhskie zaseki" reserve. Dendrology. 2004, no. 5, pp. 28-35.

46. Bobrovskii M. V. Forest soils: biotic and anthropogenic factors of formation. Eastern European forests. History in the Holocene and modern times. Edited by O. V. Smirnova. Moscow: Science, 2004, bk. 1, pp. 381-427.

47. Bobrovskii M. V. The role of windfall pedoturbations in the formation of forest soil profiles. Eurasian soil science. 2008, vol. 13, pp. 1366-1370.

48. Lutz H. J., Griswold F. S. The influence of tree roots on soil morphology. Am. J. Sci. 1939, vol. 237, pp. 389-400.

49. Trousdell K. B., Williams W. C., Nelson T. C. Damage to Recently Thinned Loblolly Pine Stands by Hurricane Donna. Journal of Forestry. 1965, vol. 63, no. 2, pp. 96-100.

50. Pyatt D. G. The soils and windthrow surveys of New-castleton Forest, Roxburghshire. Scott. For. 1966, vol. 20, pp. 175-183.

51. Lal R. Soil degradation by erosion. Land Degrad. Develop. 2001, vol. 12, pp. 519-539.

52. Gogolev A. I., Targulyan V. O. Transitional horizons of soils with argillaceous-differentiated profile as a result of pedogenic differentiation. Pedology. 1994, no. 6, pp. 5-14. 
53. Tonkonogov V. D. Argillaceous-differentiated soils of European Russia. Moscow: Institute of soils named after V. V. Dokuchaev, 1999, 156 p.

54. Tonkonogov V. D. Automorphic soil formation in tundra and taiga zones of the East European and West Siberian plains. Moscow: Institute of soils named after V. V. Dokuchaev, 2010, 304 p.

55. Lebedeva I. I., Tonkonogov V. D., Gerasimova M. I. Geographical aspects of soil memory in mesomorphic soils of some regions of Eurasia. Pedology. 2002, no. 1, pp. 33-46.

56. Gavin D. G., Brubaker L. B., Lertzman K. P. Holocene fire history of a coastal temperate rain forest based on soil charcoal radiocarbon dates. Ecology. 2003, vol. 84, pp. 186-201.

57. Talon B., Payette S., Filion L., Delwaide A. Reconstruction of the long-term fire history of an old-growth deciduous forest in Southern Québec, Canada, from charred wood in mineral soils. Quat. Res. 2005, vol. 64, pp. 36-43.

58. Gavin D. G., Hallett D. J., Hu F. S., Lertzman K. P., Prichard S. J., Brown K. J., Lynch J. A., Bartlein P., Peterson D. L. Forest fire and climate change in western North America: insights from sediment charcoal records. Front. Ecol. Environ. 2007, vol. 5, no. 9, pp. 499-506.

59. Gavin D. G. Forest soil disturbance intervals inferred from soil charcoal radiocarbon dates. Can. J. For. Res. 2003, vol. 33, pp. 2514-2518.

60. Francis J. K. Age of A2 horizon charcoal and forest structure near Porto Trombetas, Pará, Brazil. Biotropica. 2001, vol. 33, pp. 385-392.

61. Ivanov I. V., Shadrikov I. G., Asainova Z. S., Dmitrakov L. M. Space-time relationship pf soil and plant covers on the boundary of taiga and mixed forests in conditions of anthropogenic impacts. Soil processes and space-time organization of soils. Edited by V. N. Kudeyarov. Moscow: Science, 2006, pp. 78-97.

62. Carcaillet C., Thinon M. Pedoanthracological contribution to the study of the evolution of the upper treeline in the Maurienne Valley (North French Alps): methodology and preliminary data. Review of Palaeobotany and Palynology. 1996, vol. 91, no. 1, pp. 399-416.

63. Hart J. L., Horn S. P., Grissino-Mayer H. D. Fire history from soil charcoal in a mixed hardwood forest on the Cumberland Plateau, Tennessee, USA 1. The Journal of the Torrey Botanical Society. 2008, vol. 135, no. 3, pp. 401410.

64. Lafontaine G. de., Asselin H. Soil charcoal stability over the Holocene across boreal northeastern North America. Quaternary Research. 2011, vol. 76, no. 2, pp. 196-200.

65. Nelle O., Robin V., Talon B. Pedoanthracology: Analysing soil charcoal to study Holocene palaeoenvironments. Quaternary International. 2013, vol. 289, pp. 1-4.

66. Bobrovskii M. V. Effect of the historical land use on the structure of forest soils in European Russia. Eurasian Soil Science. 2010, vol. 43, no. 13, pp. 1458-1466.

67. Gerlach R., Baumewerd-Schmidt H., K. van den Borg, Eckmeier E., Schmidt M. W. I. Prehistoric alteration of soil in the Lower Rhine Basin, Northwest Germany-archaeological, ${ }^{14} \mathrm{C}$ and geochemical evidence. Geoderma. 2006, vol. 136, pp. 38-50.

68. Gerlach R., Fischer P., Eckmeier E., Hilgers A. Buried dark soil horizons and archaeological features in the Neolithic settlement region of the Lower Rhine area, NW Germany: Formation, geochemistry and chronostratigraphy. Quaternary International. 2012, vol. 265, pp. 191-204.

69. Wood W. R., Johnson D. L. A survey of disturbance processes in archaeological site formation. Advances in archaeological method and theory. 1978, vol. 1, pp. 315-370.

\section{Cnucok лumepamypы}

1. Denny, C. S. Microrelief resulting from fallen trees. Surficial Geology and Geomorphology of Potter Country, Pennsylvania / C. S. Denny, J. C. Goodlett // US Geol. Surv. Prof. Pap. - 1956. - Vol. 288. - P. 59-68.

2. Stephens, E. P. The uprooting of trees - a forest process / E. P. Stephens // Proc. Soil Sci. Amer. - 1956. - № 11. P. 113-116.

3. Lyutsau, S. V. On the role of woody plant systems in shifting of mellow fragmental masses on slopes and in relief formation / S. V. Lyutsau // Problems of geography. - M. : State publishing of geographical literature, 1959. Vol. 46. - pp. 169-177.

4. Lutz, H. T. Movement of rocks by uprooting of forest trees / H. T. Lutz // Amer. J. Sci. - 1960. - № 10. - P. $752-756$.

5. On the origin of soil cover heterogeneity in forest biocenoses / E. A. Dmitriev, L. O. Karpachevsky, M. N. Stroganova, S. A. Shoba // Problems of pedology. - M. : Science, 1978. - pp. 212-218.

6. The role of treefall in formation of soil cover structure / L. O. Karpachevsky, E. A. Dmitriev, E. A. Skvortsova, V. F. Basevich // Soil cover structure and soil resources management. - M. : Science, 1978. - pp. 37-42.

7. Dmitriev, E. A. The role of treefall in formation of soil cover in forests / E. A. Dmitriev, L. O. Karpachevsky, E. B. Skvortsova // Genesis and ecology of soils of the Central-forest state reserve. - M. : Science, 1979. pp. 111-120.

8. Basevich, V. F. Pedoturbations during treefall and their role in formation of soil cover of forest biocenoses : author's abstract of dissertation to apply for the degree of the candidate of biological sciences / Basevich V. F. M., 1981. -24 p.

9. Skvortsova, E. B. Ecological role of windfalls / E. B. Skvortsova, N. G. Ulanova, V. F. Basevich. - M. : Forest industry, 1983. $-192 \mathrm{p}$. 
10. Beatty, S. W. Influence of microtopography and canopy species on spatial patterns of forest understory plants / S. W. Beatty // Ecology. - 1984. - Vol. 65. - P. 1406-1419.

11. The Ecology of Natural Disturbance and Patch Dynamics / ed. by S. T. A. Pickett, P. S. White. - San Diego : Academic Press, 1985. - 472 p.

12. Beatty, S. W. The variety of soil microsites created by tree falls / S. W. Beatty, E. L. Stone // Agron. Pap. - 1986. Vol. 1406. - P. 539-548.

13. Tree uprooting: review of impact on forest ecology / R. J. Schaetzl, S. F. Burns, D. L. Jonson, T. W. Small // Vegetation. - 1989. - Vol. 79, № 3. - P. 165-176.

14. Tree uprooting: review of terminology, process, and environmental implication / R. J. Schaetzl, D. L. Jonson, S. F. Burns, T. W. Small // Canad. J. For. Res. - 1989. - Vol. 19, № 1. - P. 1-11.

15. Schaetzl, R. J. Effects of treethrow microtopography on the characteristics and genesis of Spodosols, Michigan, USA / R. J. Schaetzl // Catena. - 1990. - Vol. 17, № 2. - P. 111-126.

16. Hytteborn, H. Natural disturbance and gap dynamics in a Swedish boreal spruce forest / H. Hytteborn, Q. Liu, T. Verwijst // Coniferous forest ecology from an international perspective / ed. by N. Nakagoshi, F. B. Golley. Hague : SPB Academic Publishing, 1991. - P. 93-108.

17. Kuuluvainen, T. Gap disturbance, ground microtopography, and the regeneration dynamics of boreal coniferous forests in Finland : a review / T. Kuuluvainen // Ann. Zool. Fennici. - 1994. - Vol. 31. - P. 35-51.

18. Ponomarenko, E. V. Methodological approaches to analysis of succession processes in soil cover / E. V. Ponomarenko // Succession processes in reserves of Russia and problems of biological diversity preservation / edited by O. V. Smirnova, E. S. Shaposhnikov. - SPb. : RBS, 1999. - pp. 34-57.

19. Ulanova, N. G. The effects of windthrow on forest at different spatial scales: a review / N. G. Ulanova // For. Ecol. Manage. - 2000. - Vol. 135. - P. 155-167.

20. Bolysov, S. I. Biogenic relief formation on dry land / S. I. Bolysov. - M. : Geos, 2007. - Vol. 2. Zonality. - 466 p.

21. Bobrovskii, M. V. Forest soils of European Russia: biotic and anthropogenic factors of formation / M. V. Bobrovskii. - M. : Partnership of scientific publications KMK, 2010. - 359 p.

22. Armson, K. A. Forest windthrow and their influence on soil morphology / K. A. Armson, R. J. Fessenden // Soil Sci. Soc. Am. Proc. - 1973. - Vol. 37. - P. 781-783.

23. Tree uprooting: review of types and patterns of soil disturbance / R. J. Schaetzl, S. F. Burns, T. W. Small, D. L Johnson // Phys. Geogr. - 1990. - Vol. 11. - P. 277-291.

24. Allen, J. R. L. Trees and their response to wind: mid Flandrian strong winds, Severn Estuary and inner Bristol Channel, southwest Britain / J. R. L. Allen // Philosophical Transactions of the Royal Society of London B: Biological Sciences. - 1992. - T. 338, № 1286. - P. 335-364.

25. Langohr, R. Types of tree windthrow, their impact on the environment and their importance for the understanding of archaeological data / R. Langohr // Helinium. - 1993. - Vol. XXXIII, № 1. - P. 36-49.

26. Vasenev, I. I. Windfall and taiga soil formation (regimes, processes, morphogenesis of soil successions) / I. I. Vasenev, V. O. Targulyan. - M. : Science, 1995. - 247 p.

27. Kramer, M. C. Soil carbon dynamics across a windthrow disturbance sequence in southeast Alaska / M. C. Kramer, P. Sollins, R. S. Sletten // Ecology. - 2004. - Vol. 85. - P. 2230-2244.

28. Šamonil, P. The role of tree uprooting in soil formation: a critical literature review / P. Šamonil, K. Král, L. Hort // Geoderma. - 2010. - Vol. 157. - P. 65-79.

29. Mitchell, S. J. Wind as a natural disturbance agent in forests: a synthesis / S. J. Mitchell // Forestry. - 2013. Vol. 86, no 2. - P. 147-157.

30. Pawlik, Ł. The role of trees in the geomorphic system of forested hillslopes : a review / Ł. Pawlik // Earth-Science Reviews. - 2013. - Vol. 126. - P. 250-265.

31. Crossdating of disturbances by tree uprooting: can treethrow microtopography persist for 6,000 years? / P. Šamonil, R. J.Schaetzl, M.Valtera, V. Goliáš, P. Baldrian, I. Vašíčková, D. Adam, D. Janík, L. Hort // Forest Ecology \& Management. - 2013. - Vol. 307. - P. 123-135.

32. Soil mixing and genesis as affected by tree uprooting in three temperate forests / P. Šamonil, P. Daněk, R. J. Schaetzl, I. Vašíčková, M. Valtera // European Journal of Soil Science. - 2015. - Vol. 66, №. 3 - P. $589-603$.

33. White, P. S. The search for generality in studies of disturbance and ecosystem dynamics / P. S. White, A. Jentsch // Progress in Botany. - Berlin ; Heidelberg : Springler, 2001. - Vol. 62. - P. 399-449.

34. Halle, F. Tropical trees and forest: an architectural analysis / F. Halle, R. A. A. Oldeman, P. B. Tomlinson. - Berlin ; Heidelberg ; New York : Springer-Verlag, 1978. - 442 p.

35. Yamamoto, S. Gap-phase dynamics in climax forests : a review / S. Yamamoto // Biol. Sci. - 1981. - Vol. 33. P. 8-16.

36. Hibbs, D. E. Gap dynamics in hemlock-hardwood forest / D. E. Hibbs // Canad. J. For. Res. - 1982. - Vol. 12. P. 522-527.

37. Yamamoto, S. The gap theory in forest dynamics / S. Yamamoto // J. Plant Res. - 1992. - Vol. 105. - P. $375-383$.

38. Remmert, H. The mosaic-cycle concept of ecosystems - an overview / H. Remmert // Ecol. Studies. - Berlin ; Heidelberg : Springer-Verlag, 1991. - Vol. 85. - P. 1-21.

39. Vasenev, I. I. A windfall model of taiga soil formation: primary succession / I. I. Vasenev, V. O. Targulyan // Pedology. - 1994. - № 12. - pp. 5-16.

40. Vasenev, I.I. Soil successions / I. I. Vasenev. - M. : LKI publishing, 2008. - 400 p. 
41. Dzięgielewski, K. Possibilites of identification and dating of tree windthrow structures on archaeological sites (based on the examples from Podłęze. Site 17) / K. Dzięgielewski // Sprawozdania Archeologiczne. - 2007. Vol. 59. - P. 393-415.

42. Signs of windfalls in dark humic soils of the "Kaluzhskie zaseki" reserve / M. V. Bobrovskii, S. V. Loiko, G. I. Istigechev, I. V. Kritskov // Bulletin of Tomsk State University. - 2012. - № 4 (20). - pp. 7-20.

43. Loiko, S. V. Signs of windfall morphogenesis of background soils of blackish taiga (by the example of the TomYaysk interfluve) / S. V. Loiko, M. V. Bobrovskii, T. A. Novokreshchennyh // Bulletin of Tomsk State University. Biology. - 2013. - № 4 (24). - pp. 20-35.

44. Soil as it is / E. V. Ponomarenko, S. V. Ponomarenko, G. Y. Ofman, V. P. Khavkin // Nature. - 1993. - № 3. pp. 16-26.

45. Bobrovskii, M. V. Windfall disturbances in the soil cover of the "Kaluzhskie zaseki" reserve / M. V. Bobrovskii // Dendrology. - 2004. - № 5. - pp. 28-35.

46. Bobrovskii, M. V. Forest soils: biotic and anthropogenic factors of formation // Eastern European forests. History in the Holocene and modern times / M. V. Bobrovskii; edited by O. V. Smirnova - M. : Science, 2004. - Book 1. pp. 381-427.

47. Bobrovskii, M. V. The role of windfall pedoturbations in the formation of forest soil profiles / M. V. Bobrovskii // Eurasian soil science. - 2008. - Vol. 13. - P. 1366-1370.

48. Lutz, H. J. The influence of tree roots on soil morphology / H. J. Lutz, F. S. Griswold // Am. J. Sci. - 1939. Vol. 237. - P. 389-400.

49. Trousdell, K. B. Damage to Recently Thinned Loblolly Pine Stands by Hurricane Donna / K. B. Trousdell, W. C. Williams, T. C. Nelson // Journal of Forestry. - 1965. - Vol. 63, № 2. - P. 96-100.

50. Pyatt, D. G. The soils and windthrow surveys of New-castleton Forest, Roxburghshire / D. G. Pyatt // Scott. For. 1966. - V. 20. - P. 175-183.

51. Lal, R. Soil degradation by erosion / R. Lal // Land Degrad. Develop. - 2001. - Vol. 12. - P. 519-539.

52. Gogolev, A. I. Transitional horizons of soils with argillaceous-differentiated profile as a result of pedogenic differentiation / A. I. Gogolev, V. O. Targulyan // Pedology. - 1994. - № 6. - pp. 5-14.

53. Tonkonogov, V. D. Argillaceous-differentiated soils of European Russia / V. D Tonkonogov. - M. : Institute of soils named after V. V. Dokuchaev, 1999. - 156 p.

54. Tonkonogov, V. D. Automorphic soil formation in tundra and taiga zones of the East European and West Siberian plains / V. D. Tonkonogov. - M. : Institute of soils named after V. V. Dokuchaev, 2010. - 304 p.

55. Lebedeva, I. I. Geographical aspects of soil memory in mesomorphic soils of some regions of Eurasia / I. I. Lebedeva, V. D. Tonkonogov, M. I. Gerasimova // Pedology. - 2002. - № 1. - pp. 33-46.

56. Gavin, D. G. Holocene fire history of a coastal temperate rain forest based on soil charcoal radiocarbon dates / D. G. Gavin, L. B. Brubaker, K. P. Lertzman // Ecology. - 2003. - Vol. 84. - P. 186-201.

57. Reconstruction of the long-term fire history of an old-growth deciduous forest in Southern Québec, Canada, from charred wood in mineral soils / B. Talon, S. Payette, L. Filion, A. Delwaide // Quat. Res. - 2005. - Vol. 64. P. 36-43.

58. Forest fire and climate change in western North America: insights from sediment charcoal records / D. G. Gavin, D. J. Hallett, F. S. Hu, K. P. Lertzman, S. J. Prichard, K. J. Brown, J. A. Lynch, P. Bartlein, D. L. Peterson // Front. Ecol. Environ. - 2007. - Vol. 5, № 9. - P. 499-506.

59. Gavin, D. G. Forest soil disturbance intervals inferred from soil charcoal radiocarbon dates / D. G. Gavin // Can. J. For. Res. - 2003. - Vol. 33. - P. 2514-2518.

60. Francis, J. K. Age of A2 horizon charcoal and forest structure near Porto Trombetas, Pará, Brazil / J. K. Francis // Biotropica. - 2001. - Vol. 33. - P. 385-392.

61. Space-time relationship pf soil and plant covers on the boundary of taiga and mixed forests in conditions of anthropogenic impacts / I. V. Ivanov, I. G. Shadrikov, Z. S. Asainova, L. M. Dmitrakov // Soil processes and spacetime organization of soils / edited by V. N. Kudeyarov. - M. : Science, 2006. - pp. 78-97.

62. Carcaillet, C. Pedoanthracological contribution to the study of the evolution of the upper treeline in the Maurienne Valley (North French Alps): methodology and preliminary data / C. Carcaillet, M. Thinon // Review of Palaeobotany and Palynology. - 1996. - Vol. 91, № 1. - P. 399-416.

63. Hart, J. L. Fire history from soil charcoal in a mixed hardwood forest on the Cumberland Plateau, Tennessee, USA $1 /$ J. L. Hart, S. P. Horn, H. D. Grissino-Mayer // The Journal of the Torrey Botanical Society. - 2008. - Vol. 135, № 3. - P. 401-410.

64. Lafontaine, G. de. Soil charcoal stability over the Holocene across boreal northeastern North America / G. de Lafontaine, H. Asselin // Quaternary Research. - 2011. - Vol. 76, № 2. - P. 196-200.

65. Nelle, O. Pedoanthracology: Analysing soil charcoal to study Holocene palaeoenvironments / O. Nelle, V. Robin, B. Talon // Quaternary International. - 2013. - Vol. 289. - P. 1-4.

66. Bobrovskii, M. V. Effect of the historical land use on the structure of forest soils in European Russia / M. V. Bobrovskii // Eurasian Soil Science. - 2010. - Vol. 43, №. 13 - P. 1458-1466.

67. Prehistoric alteration of soil in the Lower Rhine Basin, Northwest Germany-archaeological, ${ }^{14} \mathrm{C}$ and geochemical evidence / R. Gerlach, H. Baumewerd-Schmidt, K. van den Borg, E. Eckmeier, M. W. I. Schmidt // Geoderma. 2006. - Vol. 136. - P. 38-50. 
68. Buried dark soil horizons and archaeological features in the Neolithic settlement region of the Lower Rhine area, NW Germany: Formation, geochemistry and chronostratigraphy / R. Gerlach, P. Fischer, E. Eckmeier, A. Hilgers // Quaternary International. - 2012. - Vol. 265. - P. 191-204.

69. Wood, W. R. A survey of disturbance processes in archaeological site formation / W. R. Wood, D. L. Johnson // Advances in archaeological method and theory. - 1978. - Vol. 1. - P. 315-370. 